\title{
The Ophiostoma clavatum species complex: a newly defined group in the Ophiostomatales including three novel taxa
}

\section{Riikka Linnakoski ${ }^{1,2 *}$, Robert Jankowiak ${ }^{3}$, Caterina Villari ${ }^{4,5}$, Thomas Kirisits ${ }^{6}$, Halvor} Solheim $^{7}$, Z. Wilhelm de Beer' ${ }^{2}$ Michael J. Wingfield ${ }^{2}$

${ }^{1}$ Department of Forest Sciences, University of Helsinki, P.O. Box 27, FI-00014 Helsinki, Finland

${ }^{2}$ Department of Microbiology and Plant Pathology, Forestry and Agricultural Biotechnology Institute (FABI), University of Pretoria, Pretoria, 0002, South Africa

${ }^{3}$ Institute of Forest Ecosystem Protection; Department of Forest Pathology, Mycology and Tree Physiology; University of Agriculture in Kraków, Al. 29 Listopada 46, 31-425 Kraków, Poland

${ }^{4}$ Department of Plant Pathology, Ohio State University, Columbus, OH 43210, USA

${ }^{5}$ Dipartimento di Agronomia Animali Alimenti Risorse Naturali e Ambiente, Università di Padova, Agripolis, Legnaro, Padova 35020, Italy

${ }^{6}$ Institute of Forest Entomology, Forest Pathology and Forest Protection (IFFF), Department of Forest and Soil Sciences, University of Natural Resources and Life Sciences, Vienna (BOKU), Hasenauerstraße 38, A-1190 Vienna, Austria

${ }^{7}$ Norwegian Institute of Bioeconomy Research, P.O. Box 115, 1431 Ås, Norway

*Corresponding author, e-mail: riikka.linnakoski@ helsinki.fi, tel. +358-44-533-0212

\begin{abstract}
Two species of blue-stain fungi with similar morphologies, Ophiostoma brunneociliatum and O. clavatum, are associates of bark beetles infesting Pinus spp. in Europe. This has raised questions whether they represent distinct taxa. Absence of herbarium specimens and contaminated or mistakenly identified cultures of O. brunneo-ciliatum and O. clavatum have accentuated the uncertainty regarding their correct identification. The aim of this study was to reconsider the identity of European isolates reported as O. brunneo-ciliatum and O. clavatum by applying DNA-based identification methods, and to provide appropriate type specimens for them. Phylogenetic analyses of the ITS, $\beta$ T, TEF- $1 \alpha$ and CAL gene sequences revealed that the investigated isolates represent a complex of seven cryptic species. The study confirmed that ITS data is insufficient to delineate species in some Ophiostoma species clusters. Lectotypes
\end{abstract}


and epitypes were designated for $O$. clavatum and $O$. brunneo-ciliatum, and three new species, O. brunneolum, O. macroclavatum and O. pseudocatenulatum, were described in the newly defined $O$. clavatum-complex. The other two species included in the complex are $O$. ainoae and $O$. tapionis. The results suggest co-evolution of these fungi in association with specific bark beetles. The results also confirm the identity of the fungus associated with the pine bark beetle Ips acuminatus as $O$. clavatum, while $O$. brunneo-ciliatum appears to be mainly associated with another pine bark beetle, Ips sexdentatus.

Keywords bark beetle-associated fungi; ophiostomatoid fungi; Ophiostoma brunneolum; Ophiostoma macroclavatum; Ophiostoma pseudocatenulatum

\section{INTRODUCTION}

Species of Ophiostoma Syd. (Ascomycota) include causal agents of blue-stain in timber as well as some important tree pathogens (Altenkirch et al. 2002; Kirisits 2013). These fungi produce spores in slimy droplets, which can attach to passing arthropods, especially bark beetles and mites (Wingfield et al. 1993; Kirisits 2004, 2013; Seifert et al. 2013). More than 130 species are currently recognised in the genus Ophiostoma, including a variety of sexual morphs and a continuum of asexual states ranging in complexity from sporothrix- and hyalorhinocladiella- to pesotum-like (De Beer et al. 2013). The genus includes several species complexes accommodating morphologically similar taxa. These complexes commonly include morphologically indistinguishable cryptic species, the boundaries of which can be resolved only by using multigene phylogenies (De Beer and Wingfield 2013).

In recent years, unprecedented outbreaks of the pine bark beetle Ips acuminatus (Gyll.), often accompanied by tree mortality, have been observed in Alpine Pinus sylvestris L. forests in Northern Italy, Switzerland and Southern Austria (Wermelinger et al. 2008; Krehan 2011; Colombari et al. 2012, 2013), and, unexpectedly, also in Southern Finland (Siitonen 2014). This is surprising because this bark beetle is generally known as one with low levels of aggressiveness, infesting mainly weakened, standing dead or fallen trees (Altenkirch et al. 2002). Recent outbreaks and the increasing importance of I. acuminatus as a pest have been attributed to hot and dry summers that have increased the susceptibility of pine trees to bark beetle infestation (Rebetez et al. 2004; Dobbertin et al. 2007; Wermelinger et al. 2008; Colombari et al. 2012; Siitonen 2014). 
Several fungal species are known to be associated with I. acuminatus (Kirisits 2004). The fungus most consistently reported with this bark beetle is Ophiostoma clavatum Math. (Mathiesen 1950, 1951; Rennerfelt 1950; Mathiesen-Käärik 1953; Francke-Grosmann 1952, 1963a; Käärik 1975a, 1980). Another fungus, O. brunneo-ciliatum Math.-Käärik, has also been reported in a limited number of studies (Lieutier et al. 1991; Guérard et al. 2000; Villari et al. 2012) as an associate of I. acuminatus. However, the correctness of this association remains uncertain, because of the close morphological similarity between O. brunneo-ciliatum and O. clavatum.

Ophiostoma clavatum was originally described as an important associate of I. acuminatus infesting Pinus sylvestris in Sweden (Mathiesen 1951). Later, Mathiesen-Käärik (1953) also found this fungus associated with Tomicus piniperda L. Subsequently, O. clavatum has been reported only occasionally (Francke-Grosmann 1952; Francke-Grosmann 1963a; Aoshima 1965; Käärik 1975a) until the recognition of a fungus identical to O. clavatum consistently associated with I. acuminatus in the Alps (Villari 2012; Villari et al. 2012, 2013).

Ophiostoma brunneo-ciliatum, a species that is morphologically virtually identical to O. clavatum, was first described by Mathiesen-Käärik (1953) from P. sylvestris infested by the bark beetle Ips sexdentatus Boern. in Sweden. Mathiesen-Käärik (1953, 1960) distinguished O. brunneo-ciliatum from O. clavatum based on its ecology and physiology, and its larger ascocarps and conidiomata. Subsequent to its description, several studies have reported O. brunneo-ciliatum in association with I. sexdentatus infesting Pinus spp. (Lieutier et al. 1989, 1991; Kirschner 1998, 2001; Bueno et al. 2010; Jankowiak 2012). Some studies have claimed the occurrence of this fungus as an associate of I. acuminatus (Lieutier et al. 1991; Guérard et al. 2000). Ophiostoma brunneo-ciliatum has been also found as an important associate of the larch bark beetles Ips cembrae (Heer) infesting Larix decidua Mill. in Europe (Kirisits et al. 2000; Stauffer et al. 2001; Kirisits. 2001, 2004; Jankowiak et al. 2007) and Ips subelongatus Motschulsky (in some studies treated as conspecific with I. cembrae) infesting L. kaempferi (Lamb.) Carriére in Japan (Aoshima 1965; Yamaoka et al. 1998, 2009). Other studies have reported the fungus from various bark beetle species in Europe, including Ips amitinus Eichh., I. typographus L. and Pityogenes chalcographus L. on spruce (Kirisits et al. 2000; Kirisits 2001, 2004; Jankowiak et al. 2009; Linnakoski et al. 2010; Linnakoski 2011; Repe et al. 2013), and the pine shoot beetles Tomicus minor Hartig and T. piniperda (Linnakoski et al. 2010; Linnakoski 2011).

Ophiostoma ainoae H. Solheim, another species similar to O. clavatum and O. brunneocilliatum in having spirally coiled ostiolar hyphae, could have been confused with $O$. clavatum 
and O. brunneo-ciliatum in past studies. This fungus is morphologically most similar to O. clavatum and is distinguished from that species only by the shape of ascospores and culture characteristics (Solheim 1986). In a recent study using DNA sequence-based identification methods, $O$. ainoae was surprisingly not collected from spruce infesting bark beetles in Poland (R. Jankowiak, unpublished data) despite its relatively frequent occurrence in previous years (Jankowiak 2005; Jankowiak et al. 2009).

In their original descriptions, type material was not designated for either $O$. clavatum or O. brunneo-ciliatum (Mathiesen 1951; Mathiesen-Käärik 1953). This lack of type material and the morphological similarities between the two species suggest that some of the specimens and isolates collected from I. acuminatus could have been misidentified. Moreover, it is probable that cryptic species have been overlooked in earlier studies where DNA methods were either not yet available or not applied. The aim of this study was thus to reconsider the identity and ecology of isolates from Europe previously reported as O. clavatum and O. brunneo-ciliatum, and to consider the phylogeny and taxonomy of these fungi together with other closely related species. Multigene DNA sequence analyses for four gene regions were conducted and accompanied with comparisons of morphological characteristics and ecology. This made it possible to resolve the problems relating to the typification of O. brunneo-ciliatum and O. clavatum, and to recognize and describe three novel taxa in the newly defined $O$. clavatum species complex.

\section{MATERIALS AND METHODS}

\section{Fungal isolates and herbarium specimens}

Examined material included living fungal isolates collected in previous studies, new isolates collected from Alpine forests (Fig. 1) and dried herbarium specimens (Table 1). Isolates that had not already been appropriately preserved in collections were deposited in the culture collection (CMW) of the Forestry and Agricultural Biotechnology Institute (FABI), University of Pretoria, South Africa. The ex-type strains were also deposited in the Centraalbureau voor Schimmelcultures (CBS), Utrecht, The Netherlands. Some isolates of O. clavatum are also preserved in the culture collection of the Institute of Forest Entomology, Forest Pathology and Forest Protection (IFFF), University of Natural Resources and Life Sciences, Vienna (BOKU), Austria. Herbarium specimens were deposited in the Herbarium of the University of Turku, Finland (TUR), Finland. New names and typifications were registered in MycoBank (Robert et al. 2013). 


\section{DNA extraction, PCR and sequencing}

Fungal isolates were grown on $2 \%$ malt extract agar [MEA: $20 \mathrm{~g}$ malt extract $\mathrm{l}^{-1}$ (Biolab,

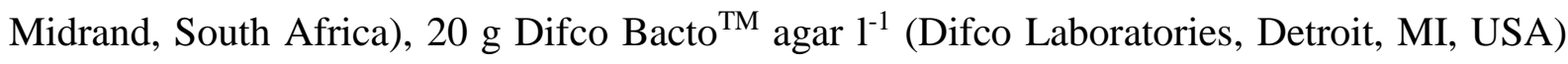
and 11 Milli-Q water] in $70 \mathrm{~mm}$ plastic Petri dishes for 1-2 weeks prior to DNA extraction. DNA was extracted using PrepMan Ultra Sample preparation reagent following the manufacturer's protocol (Applied Biosystems, Foster City, CA, USA).

Gene regions investigated in the study were the internal transcribed spacer (ITS) regions (ITS1 and ITS2) including the 5.8S gene, as well as the partial $\beta$-tubulin $(\beta \mathrm{T})$, the elongation factor 1- $\alpha($ TEF-1 $\alpha)$ and the calmodulin (CAL) genes. The ITS region was amplified using the primers ITS1-F (Gardes and Bruns 1993) and ITS4 (White et al. 1990). The partial $\beta$ T gene was amplified using the primers T10 (O’Donnell and Cigelnik 1997) and Bt2b (Glass and Donaldson 1995). The TEF-1 $\alpha$ gene region was amplified using the primers EF2F (Marincowitz et al. 2015) and EF2R (Jacobs et al. 2004), which were replaced in some cases with the primer pair F-728F (Carbone and Kohn 1999) and EF2 (O'Donnell et al. 1998). The CAL gene was amplified using the primer pairs CL2F and CL2R (Duong et al. 2012) or CL3F and CL3R (Musvuugwa et al. 2015).

Amplification of the gene regions was performed in a $25 \mu 1$ reaction mixture. The reaction mixture contained $0.15 \mu \mathrm{l}$ of MyTaq ${ }^{\mathrm{TM}}$ DNA Polymerase (5 U/ $\mu \mathrm{l}$ ) (Bioline, Massachusetts, USA), $2.5 \mu$ of MyTaq ${ }^{\mathrm{TM}}$ Reaction Buffer (5×) containing dNTPs, $\mathrm{MgCl}_{2}$ and enhancers for the optimal performance, and $0.50 \mu \mathrm{L}$ of each primer (for EF2F and CAL degenerate primers $20 \mathrm{mM}$ stock concentration; for other primers $10 \mathrm{mM}$ stock concentration) (Whitehead Scientific Ltd, Cape Town, South Africa). PCR reactions were performed using an ABI 2720 Thermal Cycler (Applied Biosystems, Foster City, CA, USA) with the following conditions: an initial denaturation step at $95{ }^{\circ} \mathrm{C}$ for $2 \mathrm{~min}$, followed by 35 cycles of $30 \mathrm{~s}$ at $94{ }^{\circ} \mathrm{C}, 30 \mathrm{~s}$ at 55 ${ }^{\circ} \mathrm{C}$ and $1 \mathrm{~min}$ at $72{ }^{\circ} \mathrm{C}$, and a final chain elongation at $72{ }^{\circ} \mathrm{C}$ for $7 \mathrm{~min}$. PCR products were visualised under UV light after staining $5 \mu \mathrm{L}$ aliquots with $2 \mu \mathrm{L}$ of GelRed ${ }^{\mathrm{TM}}$ Nucleic Acid Gel Stain (Biotium, Hayward, CA, USA) and separation on a $1 \%$ agarose gel. Successfully amplified products were purified using the Exo-SAP protocol: the remaining PCR product (20 $\mu \mathrm{l})$ was mixed with $8 \mu \mathrm{l}$ of Exo-SAP [5 $\mu 1$ of Exonuclease I (20 U/ $\mu \mathrm{L})$ (Fermentas, Vilnius, Lithuania) and $100 \mu \mathrm{L}$ of Shrimp Alkaline Phosphatase (1 U/ $\mu \mathrm{L}$ ) (Roche Diagnostics, Indianapolis, USA) in a $1000 \mu \mathrm{L}$ reaction mixture], and incubated at $37{ }^{\circ} \mathrm{C}$ for 15 minutes, followed by immediate incubation at $80{ }^{\circ} \mathrm{C}$ for 15 minutes. 
The sequencing reactions were performed in a $12 \mu \mathrm{l}$ reaction mixture. The reaction mixture contained $0.5 \mu \mathrm{L}$ of BigDye ${ }^{\circledR}$ Terminator v3.1 Ready Reaction mixture (Perkin-Elmer Applied Biosystems, Warrington, UK), $2.1 \mu \mathrm{L}$ of sequencing buffer, $1 \mu \mathrm{L}$ of either the forward or reverse primer (10 or $20 \mathrm{mM}$ stock concentration) and $2 \mu \mathrm{L}$ of cleaned PCR product. The primers used for sequencing the ITS, the TEF- $1 \alpha$ and CAL gene regions were the same as those used for PCR. For sequencing the partial $\beta$ T gene, the T10 primer was replaced with the primer Bt2a (Glass and Donaldson 1995). The thermal cycling conditions for sequencing reactions were: 25 cycles of $10 \mathrm{~s}$ at $96{ }^{\circ} \mathrm{C}, 5 \mathrm{~s}$ at $55^{\circ} \mathrm{C}$ and $4 \mathrm{~min}$ at $60{ }^{\circ} \mathrm{C}$. Sequencing products were cleaned using ethanol/salt precipitation and dried in a laminar flow overnight. Sequencing was done on the ABI Prism 3100 DNA Analyzer (Applied Biosystems, Foster City, CA, USA) at the DNA Sequencing Facility of the Forestry and Agricultural Biotechnology Institute (FABI), University of Pretoria.

\section{Sequence analyses}

Consensus sequences were determined using the program Geneious R6 (Biomatters Ltd, Auckland, New Zealand), after which a preliminary identification of the isolates was obtained using a BLAST search against the GenBank nucleotide database (http://www.ncbi.nlm.nih.gov). The sequences were deposited in GenBank and their accession numbers are presented in Table 1.

Individual data sets for the ITS, the $\beta$ T, the TEF- $1 \alpha$ and the CAL gene regions were used for phylogenetic analyses. Data sets were compiled and edited in Molecular Evolutionary Genetic Analysis (MEGA) v6.06-mac (Tamura et al. 2013). Sequence alignments were performed using the online version of MAFFT v7 (Katoh and Standley 2013). The ITS data set was aligned using the FFT-NS-i strategy with a 200PAM/ $/=2$ scoring matrix, a gap opening penalty of 1.53 and an offset value of 0.00 . The $\beta$ T, the TEF- $1 \alpha$ and the CAL data sets consisted of closely related DNA sequences and were thus aligned using the G-INS-i strategy with a $1 \mathrm{PAM} / \kappa=2$ scoring matrix, a gap opening penalty of 1.53 and an offset value of 0.00 . Aligned data sets of the protein-coding genes were compared to gene maps constructed by Yin et al. (2015) to determine the presence or absence of introns and confirm that introns and exons were appropriately aligned.

Phylogenetic analyses were performed for each of the data sets using three different methods: maximum likelihood (ML), maximum parsimony (MP) and Bayesian inference (BI). ML analyses were performed using RAxML v7.0.4 (Stamakis 2014) on the CIPRES Science 
Gateway v3.3 (Miller et al. 2010) employing the GTR substitution matrix and a rapid bootstrap analysis (Stamakis et al. 2008) to search for the best-scoring ML tree. The number of bootstrap replicates was estimated using the boot stopping criterion implemented in RAxML (Pattengale et al. 2010). MP analyses were conducted using PAUP v. $4.0 \mathrm{~b} 10$ (Swofford 2002). Gaps and missing data were included in the MP analyses as a fifth character. BI analyses based on a Markov Chain Monte Carlo (MCMC) simulation were carried out with MrBayes v3.1.2 (Ronquist and Huelsenbeck 2003). The best fitting evolutionary models for each data set were determined using MrModeltest v2.3 (Nylander 2004) based on the Akaike Information Criterion (AIC). The MCMC chains were run for five million generations using a sample frequency of 100 (resulting in 50000 trees). Burn-in values were calculated for the respective data sets, and all sampled trees having lower than the burn-in values were discarded. The remaining trees were used to construct majority rule consensus trees.

\section{Morphological characterization}

Morphological characteristics for selected isolates and herbarium specimens chosen to represent the type specimens were examined. Cultures were grown on $2 \%$ MEA and on $2 \%$ oat meal agar (OA; $15 \mathrm{~g}$ oatmeal, $20 \mathrm{~g}$ Difco Bacto ${ }^{\mathrm{TM}}$ agar and $1 \mathrm{~L}$ Milli-Q water) with and without host tree twigs that in some cases induced conidiophore and ascocarp formation. Autoclaved twigs with bark were placed at the centres of $2 \%$ MEA and OA agar plates. In an attempt to obtain sexual structures for morphological descriptions of species revealed by the phylogenetic analyses, crosses between different isolates of the same species were made in all possible combinations on Petri dishes to which autoclaved host tree twigs had been added (Grobbelaar et al. (2010). To serve as controls, isolates were inoculated individually on Petri dishes. Cultures were incubated at $25^{\circ} \mathrm{C}$ and inspected regularly for the presence of fruiting structures.

Morphological characteristics were examined by mounting the sexual and asexual fruiting structures in $80 \%$ lactic acid on glass slides, and these were observed using a Zeiss Axioskop microscope (Carl Zeiss, Germany) with a AxioCam ICc3, and a Nikon Eclipse 50i microscope (Nikon Corporation Tokyo, Japan) with a Nikon DS-Fi1 camera system (Nikon Corporation, Tokyo, Japan) to capture photographic images. Measurements were made of 50 each of the taxonomically relevant structures where this was possible. Averages, ranges and standard deviations were computed for the measurements. The measurements are presented in the format '(min-)(mean-SD)-(mean+SD)(-max)'. For scanning electron microscopy (SEM), specimens were prepared and studied as described by Linnakoski et al. (2009). 


\section{Culture characteristics}

Growth characteristics of isolates in pure culture were considered for three representative isolates (Table 1) of each of the studied species following the method described by Linnakoski et al. (2009). Five replicate plates per isolate were used for each temperature $(5,10,15,20,25$, 30 and $35^{\circ} \mathrm{C}$ ). Colony diameters (three measurements per plate) were determined 4, 6 and $8 \mathrm{~d}$ after inoculation. From the diameter measurements, radial growth rates in $\mathrm{mm} /$ day were calculated. Mean radial growth rates ( \pm standard deviation) at each temperature were calculated as an average of readings for each species.

\section{RESULTS}

\section{DNA sequence analyses}

The amplified DNA fragments were approximately $600 \mathrm{bp}$ long for the ITS gene regions, 500 bp long for the partial $\beta \mathrm{T}, 900 \mathrm{bp}$ long for the TEF-1 $\alpha$, and $700 \mathrm{bp}$ long for the CAL genes. The aligned data set for the ITS gene region included 84 taxa and 782 characters (with gaps). The $\beta T$ data set consisted of 67 taxa and 333 characters (with gaps), and included partial intron 3, exon 4, intron 4, exon 5 (no intron 5) and partial exon 6. The TEF-1 $\alpha$ data set consisted of 34 taxa and 809 characters (with gaps), including intron 3, exon 4 (no intron 4), and partial exon 5. The CAL data set consisted of partial intron 3, exon 4, intron 4, exon 5 (no intron 5), exon 6 , and partial intron 6. Intron 4 included a highly variable microsatellite region that was excluded in further analyses. The final aligned CAL data set used in the analyses consisted of 34 taxa and 470 characters (with gaps). The BI, ML and MP analyses for each data set produced trees with similar topologies (Fig. 2-5). The best-fitting substitution model selected for BI analyses was $\mathrm{GTR}+\mathrm{I}+\mathrm{G}$ for all the data sets.

The ITS data did not distinguish clearly between the closely related species considered in this study, but was useful to assign isolates to species complexes (Fig. 2). Therefore, the ITS sequences were used to show the placement of the isolates within Ophiostoma sensu lato (Fig. 2). Although monophyly was not strongly supported, the phylogenetic analyses of the ITS gene region (Fig. 2) showed that the isolates considered and defined by the type strain of each species in the ITS tree form a distinct complex of species within Ophiostoma sensu stricto.

The partial $\beta \mathrm{T}$ gene was used to identify isolates to species level (Fig. 3). The $\beta \mathrm{T}$ data set included sequences for all the living isolates considered in this study (Table 1). The TEF-1 $\alpha$ and the CAL data were used to further confirm the identities of the isolates to species level (Fig. 
4-5). The sequences of the type isolates and sequences that represent the isolates with most variation in respect to their origin from different host trees, bark beetle vectors and locations were included in the TEF- $1 \alpha$ and the CAL data sets. Variation found in the $\beta$-tubulin gene region was sufficient to distinguish between the different species in the complex. In the $\beta T$ data set, 86/333 (25.8\%) positions were variable. Excluding the outgroup species (O. tapionis Linnakoski, Z.W. De Beer \& M.J. Wingf. and O. ainoae), intraspecific sequence variation was found in all species in the complex. Intraspecific variability of the $\beta \mathrm{T}$ gene was observed in 19 positions within $O$. brunneo-ciliatum, in two positions within $O$. brunneolum, in two positions within $O$. clavatum, in one position within $O$. macroclavatum, and in 10 positions within $O$. pseudocatenulatum.

The three protein-coding genes revealed better resolution for species level assignment than the ITS data. Based on the $\beta$ T and the TEF- $1 \alpha$ data, isolates resided in seven well-supported lineages (Figs. 3-4). The CAL gene complemented the other gene regions, but did not provide well-supported separation of the species in the complex (Fig. 5). Two of the taxonomically well-defined species, Ophiostoma tapionis and O. ainoae, formed distinct lineages that reside peripheral to the complex, and this was also supported based on the ITS sequence data (Figs. 2-5). However, both fungi are morphologically similar to other species investigated here, and thus meet the criteria for the species complex.

\section{Morphological characteristics}

Herbarium specimens and cultures of isolates examined had several morphological similarities, which justified treating them as a complex of species. When ascocarps were present, the most distinct characteristics common in the herbarium specimens and the isolates were the brown, spirally coiled ostiolar hyphae and ascospores with a cylindrical to rectangular shape in side view. The cultures on MEA were typically hyaline at first, later becoming dark-pigmented (brown to almost black). Irregularly arranged isolated patches of pesotum-like, tall macronematal conidiomata with brush-like heads were produced infrequently in most cultures. In addition, mononematous conidiophores were present in most cases. The dimensions of most morphological structures were highly variable and overlapped among species in the complex. For some species in the complex, information related to their ecology was taxonomically informative.

The colors of the colonies of some of the isolates (CBS $117572=$ CMW 5212, CMW 5214, CBS 117591, CMW 41049 and CMW 41050; Table 1) were distinctly lighter (hyaline/white) than those of other isolates, which were generally brown. These relatively old isolates are likely 
to have lost their ability to produce pigment due to long-term storage and frequent subculturing.

Crosses in culture for isolates of $O$. clavatum, O. brunneo-ciliatum and $O$. tapionis did not result in the formation of sexual structures, similar to previous findings for these taxa (Mathiesen 1951, Mathiesen-Käärik 1953, Linnakoski et al. 2010). This was also the case for $O$. ainoae and the one of the undescribed taxa (O. brunneolum). Sexual structures were found in crosses for the other two undescribed taxa (O. macroclavatum and O. pseudocatenulatum), but not in the control plates, suggesting that these species are heterothallic. Morphology of the sexual states of these two species are described in the diagnosis below.

\section{Taxonomy}

Based on the phylogenetic analyses for multiple gene regions, as well as the morphological characteristics and ecology, the isolates studied formed seven distinct lineages that represent discrete taxa. These taxa make up a distinct species complex within Ophiostoma s. str. (De Beer and Wingfield 2013) that is defined here as the O. clavatum complex, named after the first species to be described in the complex. Two of these taxa, O. ainoae and O.tapionis, are previously described and well-defined species that are now assigned to the $O$. clavatum complex. Two other lineages include isolates of O. brunneo-ciliatum and O. clavatum. Typification of both these species is resolved below by designating lectotypes and epitypes for them. The remaining three lineages represent novel taxa that are, herewith, formally described. A complete nomenclator is provided for all taxa in the species complex. Country, host, and insect associate reports that have been confirmed using comparisons of multigene DNA sequence data, are annotated with an asterisk $(*)$.

Ophiostoma ainoae H. Solheim, Nord. J. Bot. 6:201 (1986). MB 103626.

Descriptions: Solheim (1986, p. 201, Fig. 1); Yamaoka et al. (1997, pp 1219-20, Fig. $12-$ 17).

Phylogenetic data: Okada et al (1998); Hausner and Reid (2003); Gebhardt et al. (2005); Zipfel et al. (2006); Linnakoski et al. (2008, 2010); De Beer and Wingfield (2013); Repe et al. (2013).

Original reports in literature: Solheim (1986, 1992, 1993); Harding (1989); Pashenova et al. (1995); Yamaoka et al. (1997); Grubelnik (1998); Viiri (1997); Kirschner (1998, 2001); Kirisits et al. (2000); Jankowiak (2004, 2005); Viiri and Lieutier (2004); Sallé et al. (2005); 
Jankowiak et al. (2009); Kirisits (2010); Linnakoski et al. (2010)*; Jankowiak and Kot (2011); Repe et al. (2013)*.

Type material: NORWAY, Akerhus, Ås, Slørstad, from Picea abies infested by Ips typographus, 11 June 1980, H. Solheim, holotype CBS H-3559, culture ex-holotype CBS $205.83=$ CMW $1037=$ NFRI 80-48/15 and 80-69/27 = IMI 285082.

Other specimens examined: NORWAY, Akerhus, Ås, from Picea abies infested by Ips typographus, 1980, H. Solheim, CBS 118672 = CMW 1903; RUSSIA, Ohtama, Lake Vodlajärvi, from Picea abies infested by Ips typographus, June 2004, J. Ahtiainen, CBS 128299 = CMW 23123.

Host trees: Larix sibirica, Picea abies*, Picea jezoensis, Pinus sylvestris

Insect associates: Crypturgus pusillus, Dryocoetes autographus, Hylurgops glabratus, Hylurgops palliatus, Ips cembrae, Ips typographus*, Ips typographus japonicus, Ips sexdentatus, Orthotomicus laricis, Pityogenes chalcographus*, Pityogenes bidentatus, Pityophthorus pityographus, Polygraphus poligraphus

Known distribution: Austria, Denmark, Germany, Finland*, France, Japan, Norway*, Poland, Russia*, Slovenia*, Sweden

Notes: The species was first mentioned by Käärik (1975b) as 'Ceratocystis gr. clavata'. Perithecia in $O$. ainoae isolates from spruce in Europe have been observed only rarely. Based on DNA sequence data, $O$. ainoae has been confirmed to occur only on P. abies and in association with the spruce-infesting bark beetles I. typographus and P. chalcographus (Linnakoski et al. 2010; Repe et al. 2013). Reports of this species from larch- and pine-infesting bark beetles will, therefore, require confirmation, as they may refer to other members in the O. clavatum species complex. Yamaoka et al. (1997) reported this fungus, based on morphology, as an associate of I. typographus japonicus Niijima infesting Picea jezoensis (Sieb. \& Zucc.) Carr. Our assumption is that the Japanese isolates possibly represent an undescribed species, for which the identity needs to be confirmed based on DNA sequence comparisons. A species similar to O. ainoae, the taxonomic placement of which requires further study, has been reported from Bhutan in association with the bark beetle Ips schmutzenhoferi Holzschuh on Picea spinulosa (Griffith) A. Henry and Pinus wallichiana A. B. Jacks. (Kirisits et al. 2013). 
Ophiostoma brunneo-ciliatum Math.-Käärik, Medd. Statens Skogsforskningsinst. 43:44 (1953). MB 302071. Fig. 6.

三Ceratocystis brunneo-ciliata (Math.-Käärik) J. Hunt, Lloydia 19:32 (1956).

Descriptions: Mathiesen-Käärik (1953, pp 41-45, Fig. 2); Hunt (1956, p. 32); Aoshima (1965); Upadhyay (1981, p. 74, Fig. 236-241); Yamaoka et al. (1998, p. 371, Fig. 11-15).

Phylogenetic data: Hausner and Reid (2003); Linnakoski et al. (2010); Jankowiak (2012); De Beer and Wingfield (2013).

Original reports in literature: Mathiesen-Käärik (1953); Redfern et al. (1987); Lieutier et al. (1989, 1991); Yamaoka et al. (1998, 2009), Kirisits et al. (2000); Stauffer et al. (2001); Jankowiak et al. (2007, 2009); Linnakoski et al. (2010)*, Jankowiak (2012)*; Repe et al. $(2013)^{*}$.

Type material: SWEDEN, Lule Lappmark, Jokkmokk, Murjek, from Pinus sylvestris infested by Ips sexdentatus, 9 September 1952, E. Rennerfelt, lectotype (designated here, MBT 204694) UPS:BOT:F-130962; POLAND, Pateraki, from galleries of Ips sexdentatus infesting Pinus sylvestris, 20 May 2011, R. Jankowiak, reference specimen TUR 205571, reference culture CBS $141266=$ CMW 39827.

Other specimens examined: SWEDEN, Lule Lappmark, Jokkmokk, Murjek, from Pinus sylvestris infested by Ips sexdentatus, 9 September 1952, E. Rennerfelt, UPS:BOT:F-130963, UPS:BOT:F-130964, UPS:BOT:F-130965, UPS:BOT:F-130967, BPI 595721; POLAND, Wierzchosławice, from galleries of Ips cembrae infesting Larix decidua, 20 May 2011, $R$. Jankowiak, CBS 141267 = CMW 39828; POLAND, Babimost, from galleries of Ips sexdentatus infesting Pinus sylvestris, 05 August 2010, R. Jankowiak CBS 141268 = CMW 39842.

Host trees: Picea abies*, Pinus sylvestris*, Larix decidua*, Larix kaempferi

Insect vectors: Ips acuminatus, Ips amitinus*, Ips cembrae*, Ips sexdentatus*, Ips subelongatus

Known distribution: Austria, Japan, Sweden, Poland*, Slovenia

Notes: Ophiostoma brunneo-ciliatum was originally described from I. sexdentatus infesting P. sylvestris in Sweden (Mathiesen-Käärik 1953). No type specimen was formally designated for the species. Mathiesen-Käärik (1953) studied the specimens collected by Rennerfelt in 1946 and 1952. The 1952 collection is preserved in the Museum of Evolution, 
University of Uppsala, Sweden, and includes six specimens of O. brunneo-ciliatum (UPS:BOT:F-130962-130967). Hunt (1956) studied some of these specimens, deposited one of them (AM-K 12-1) in the U.S. National Fungus Collections (BPI 595721), and made a new combination in Ceratocystis for the species. In the present study, one of the UPS specimens is designated as a lectotype of O. brunneo-ciliatum. Villari (2012) showed that the only living culture from the original material (CBS $149.54=$ CMW 1029) was contaminated. We obtained a fresh isolate (CBS $141266=$ CMW 39827) from Poland, collected from the same host tree and the same bark beetle species as that linked to the original collection. The sexual state and synnematal asexual state of the latter material (Fig. 6 d-e) were observed only in the galleries of I. sexdentatus on P. sylvestris, never in culture. This is in agreement with the observations of Mathiesen-Käärik (1953). The mononematal morphology and culture characteristics of this isolate corresponded to the original description (Fig. 6, Table 2). Since the new isolate did not originate from the same country as the lectotype, it does not meet the requirements for epitypification suggested by Ariyawansa et al. (2014). We have, therefore, designated a dried culture of this isolate (TUR 205571) as a reference specimen for the species.

The host tree and beetle vector appear to provide important information in support of the taxonomic characteristics of $O$. brunneo-ciliatum. Isolates for which the identity was confirmed in this study using DNA sequence analysis originated either from I. sexdendatus infesting P. sylvestris or from I. cembrae infesting L. decidua (Table 1). Repe et al. (2013) reported O. brunneo-ciliatum from I. amitinus based on a sequence of the ITS gene region. These and other, solely morphology-based reports of O. brunneo-ciliatum in association with I. amitinus (Kirisits et al. 2000; Jankowiak et al. 2009) should be confirmed with comparisons for multiple gene regions, because the ITS data does not allow definitive species level identification in the complex. Likewise, O.pseudocatenulatum also occurs in association with I. cembrae on L. decidua (see below), raising doubts regarding the identity of isolates assigned to O. brunneociliatum in previous studies on the mycobiota of this bark beetle species (Kirisits et al. 2000; Stauffer et al. 2001; Jankowiak et al. 2007). Yamaoka et al. (1998, 2009) reported O. brunneociliatum as a dominant associate of I. subelongatus infesting L. kaempferi, but confirmation of species identity based on DNA sequence data is needed. Taking into account that substantial differences in the assemblages of ophiostomatoid fungi associated with I. cembrae in Europe and with I. subelongatus in Japan have been documented (Stauffer et al. 2001; Yamaoka et al. 2009; Masuya et al. 2013), the Japanese isolates could represent an undescribed species.

Isolates of O. brunneo-ciliatum showed considerable variation in culture color that ranged from light brown to almost black (Fig. $6 \mathrm{f}$ ). However, this variation could not be linked to 
different host trees or bark beetle associates. In addition, micro-morphological comparisons showed no differences among the different isolates and together with the sequence data, it is clear that they belong to a single taxon. Measurements of the sexual and asexual structures also corresponded well with those in previous descriptions of O. brunneo-ciliatum (Fig. 6, Table 2).

Ophiostoma brunneolum Linnakoski, Z.W. De Beer \& M.J. Wingf., sp. nov. MB 816636. Fig. 7.

Etymology: The epithet refers to the brown colony color of this species.

Sexual state not observed. Conidiophores micronematous. Hyalorhinocladiella-like asexual state present (Fig 7a-b). Conidiogenous cells arising directly from hyphae, (5-)14$28(-35) \times 1-1.5 \mu \mathrm{m}$. Conidia hyaline, cylindrical, (3-)4-6(-7.5) $\times(1-) 1.5-2(-2.5) \mu \mathrm{m}$, occasionally produced directly from hyphae. Secondary conidia occasionally produced. Culture characteristics: colonies on $2 \%$ MEA hyaline at first, later becoming brown in the center, hyphae superficial, aerial mycelium sparse (Fig. 7c.). Optimal growth temperature at $25^{\circ} \mathrm{C}$. Culture growth rates $4.3 \mathrm{~mm} / \mathrm{d}( \pm 0.2)$ at $20^{\circ} \mathrm{C}$ and $5.6 \mathrm{~mm} / \mathrm{d}( \pm 0.2)$ at $25^{\circ} \mathrm{C}$. No growth observed at $5^{\circ} \mathrm{C}$ and at $35^{\circ} \mathrm{C}$.

Type material: RUSSIA, Ohtama, Vodlajärvi, from Picea abies infested with Ips typographus, September 2004, J. Ahtiainen, holotype TUR 205572, culture ex-holotype CBS 128227 = CMW 23143; RUSSIA, Ohtama, Vodlajärvi, from Picea abies infested with Ips typographus, September 2004, J. Ahtiainen, paratype TUR 205573, culture ex-paratype CBS 141078 = CMW 23142; RUSSIA, Ohtama, Vodlajärvi, from Picea abies infested with Ips typographus, September 2004, J. Ahtiainen, paratype TUR 205574, culture ex-paratype CBS 141269 = CMW 23144.

\section{Host trees: Picea abies*}

Insect vectors: Ips duplicatus*, Ips typographus*

Known distribution: Czech Republic*, Russian Karelia*

Notes: Only a hyalorhinocladiella-like asexual state is currently known for $O$. brunneolum, which is similar that of $O$. tapionis that also resides in this complex. Isolates of this species were previously recognised as $O$. brunneo-ciliatum and treated as members of the Ophiostoma ips complex (Linnakoski et al. 2010). 
Ophiostoma clavatum Math., Svensk Bot. Tidskr. 45:222 (1951). MB 302072. Figs 8-9.

三 Ceratocystis clavata (Math.) J. Hunt, Lloydia 19:37 (1956).

Descriptions: Mathiesen (1950, p. 298, Fig. 10), Mathiesen (1951, pp 219-223, Fig. 5), Hunt (1956, pp 37-38), Upadhyay (1981, p. 137).

Phylogenetic data: no previous data available.

Original reports in literature: Mathiesen (1950, 1951); Rennerfelt (1950); MathiesenKäärik (1953); Francke-Grosmann (1952, 1963a); Aoshima (1965); Käärik (1975); Villari $(2012)^{*}$; Villari et al. (2013)*.

Type material: SWEDEN, Dalarna, Hamra, from galleries of Ips acuminatus infesting Pinus sylvestris, 18 August 1950, E. Rennerfelt, lectotype (designated here, MBT 204695) UPS:BOT:F-130972; SWEDEN, Lunsen, Uppsala, from Ips acuminatus infesting Pinus sylvestris, 4 June 2009, C. Villari, epitype (designated here, MBT 204696) TUR 205575, culture ex-epitype CBS $141080=$ CMW 37983.

Other specimens examined: ITALY, Val Venosta, from Ips acuminatus infesting Pinus sylvestris, 27 November 2008, C. Villari, CMW 37986; FRANCE, Var, from Pinus sylvestris infested with Ips acuminatus, 1997, A. Yart, herbarium specimen TUR 205576, culture CBS 141274 = CMW 37988; AUSTRIA, Carinthia, Bleiberg, from Pinus sylvestris infested with Ips acuminatus, 10 September 2012, T. Kirisits \& G. Hoch, herbarium specimen TUR 205577, culture CBS $141183=$ IFFF AC/1/IV/2 = CMW 41123.

Host trees: Pinus sylvestris*, Picea abies

Insect vectors: Ips acuminatus*, Ips sexdentatus, Orthotomicus proximus, Tomicus piniperda

Known distribution: Austria*, France*, Germany, Italy*, Japan, Norway*, Sweden*, former Yugoslavia

Notes: Rennerfelt (1950) first reported this species as Ophiostoma I from P. sylvestris infested by I. acuminatus in Sweden. Based on the material of Rennerfelt, Mathiesen (1951) provided a morphological description and named the fungus O. clavatum, but she did not designate a type specimen. The specimens of Mathiesen (who published later under the surnames Mathiesen-Käärik and Käärik) were originally stored in the herbarium of the Statens Skogforskningsinstitut, Experimentalfältet, Sweden. An O. clavatum specimen (AM-K 8-1) was studied (Table 3) by Hunt (1956) and Upadhyay (1981). Neither of these authors was able 
to find sexual fruiting structures in this specimen, which could not be located for the present study. Nevertheless, Hunt (1956) considered the species valid and provided a new combination in Ceratocystis. Upadhyay (1981) considered the species as a nomen dubium due to the lack of sexual fruiting structures. De Beer et al. (2013) consequently suggested that the name O. clavatum should be resurrected by epitypification.

The original specimen of E. Rennerfelt (UPS:BOT:F-130972) is preserved in the herbarium of the Museum of Evolution, Uppsala. In the absence of a holotype, we have designated this specimen as a lectotype of $O$. clavatum. Unfortunately, the specimen lacks the pesotum-like asexual state of the fungus (Mathiesen 1951, p. 221, Fig. 5c). However, the line drawings of Mathiesen (1951), who studied this specimen, clearly depict the asexual state (Fig. 9). The original living cultures were deposited at the CBS, but the isolate deposited as O. clavatum at the CBS by Mathiesen-Käärik (CBS 135.51 = CMW 1028) has been identified as Ophiostoma minus (Hedgc.) Syd. (Villari 2012). Two isolates from the Norwegian Institute of Bioeconomy Research, Ås, Norway (CMW 41041 and CMW 41042) (Table 1) could represent original material from Mathiesen's (1951) description. Unfortunately, the labels of these cultures have been lost and, therefore, their origin remains uncertain. Sequences of these isolates are included in the phylogenetic analyses arising from the present study and they group with other O. clavatum isolates (Figs. 3-5). In the absence of other available authenticated material, we designate a recently collected, morphologically similar isolate originating from the same host tree species, associated bark beetle species and geographical location where the fungus was originally collected, as epitype of $O$. clavatum.

Subsequent to its original description, $O$. clavatum also has been reported from other pineinfesting bark beetles, including I. sexdentatus, Orthotomicus proximus Eichh. and T. piniperda (Käärik 1973, 1975a), as well as from P. abies (Käärik 1980). However, no material exists from these reports and the host information remains to be confirmed based on new isolations and DNA sequence data. For the present, $O$. clavatum should best be treated as an associate of only I. acuminatus infesting P. sylvestris. Ascomata develop only rarely in culture (MathiesenKäärik 1951), and in this study the production of the sexual stage was not observed. The sexual stage has been observed only on naturally infected wood. Isolates of $O$. clavatum produce both mononematous to synnematous conidiophores in culture. The typical tall, brush-like conidiomata were rare in most isolates growing on MEA and were more commonly produced on OA. Comparisons of cultures and morphological characteristics showed no differences among the isolates originating from different regions (Table 1). The cultures were dark brown 
to almost black (Fig. 8). Measurements of the sexual and asexual structures corresponded well with those in previous descriptions of O. clavatum (Fig. 8, Table 3).

Ophiostoma macroclavatum Linnakoski, Z.W. De Beer \& M.J. Wingf., sp. nov. MB 816637. Fig. 10 .

Etymology: The epithet refers to the size and shape of the synnematous conidiophores that distinguish this species from the other species in the complex.

Sexual state rarely produced when two strains of opposite mating type are paired on agar with wood (sterilised spruce twigs). Ascomata superficial on media (Fig. 10a), bases dark, globose, (133-)158-195(-217) $\mu \mathrm{m}$ diam, sparsely ornamented with brown hyphal hairs (11)17-35(-46) $\mu \mathrm{m}$ long, 1-1.5 $\mu \mathrm{m}$ wide at the apex, 1.5-2 $\mu \mathrm{m}$ wide at the base, necks black, straight or slightly curved, (467-)650-918(-1010) $\mu \mathrm{m}$ long, (29-)33-44(-52) $\mu \mathrm{m}$ wide at the base, (12-)14-19(-24) $\mu \mathrm{m}$ wide at the apex. Necks have pointed, knob-like protrusions near the base (Fig. 10a). Ostiolar hyphae absent or present (Fig. 10a,c), spirally coiled, septated, brown, becoming hyaline towards apex, (7-)9-11(-12) in number, (14-)19-33(-144) $\mu \mathrm{m}$ long, $(1-) 1.5-2.5(-3) \mu \mathrm{m}$ wide at the base, $1-1.5(-2) \mu \mathrm{m}$ wide at the apex. Asci not observed. Ascospores one-celled, cylindrical to rectangular in side view, $(2-) 3-3.5(-4) \times 1-1.5 \mu \mathrm{m}$ (Fig. 10b). Conidiophores macronematous, synnematous pesotum-like, spirally coiled (Fig. 8d-e), hyaline, stalk bases occasionally pale brown, (2184-)3117-5172(-6330) $\mu \mathrm{m}$ long including capitulum, (27-)58-111(-137) $\mu \mathrm{m}$ wide at the base; conidiophore heads (108-)223-577(-887) $\mu \mathrm{m}$ wide, composed of brush-like masses of hyphae. Conidiogenous cells $(15-) 22-34(-46) \times$ 1-1.5 $\mu \mathrm{m}$; conidia hyaline, one-celled, cylindrical, $(3.5-) 5-7(-8) \times 1.5-2(-3) \mu \mathrm{m}$ (Fig. 10f), aggregating into a cream-colored mucilaginous mass surrounding the conidiophore heads (Fig. 10d). Synnematal asexual state rare on malt extract agar, more commonly produced on oatmeal agar. Conidiophores first formed in the center of colony, later found in irregularly arranged isolated patches. Hyalorhinocladiella-like micronematal asexual state present (Fig 10g). Conidiogenous cells arising directly from hyphae, (7-)11-21(-26) $\times 1-1.5) \mu \mathrm{m}$; conidia hyaline, cylindrical, 4-5.5(-7) $\times 1-1.5(-2) \mu \mathrm{m}$. Culture characteristics: Colonies on $2 \%$ MEA first hyaline, later becoming olivaceous black (Fig. 10h), mycelium superficial on agar, aerial mycelium sparse. Growth rates $4.7 \mathrm{~mm} / \mathrm{d}( \pm 1.0)$ at $20^{\circ} \mathrm{C}$ and $6.3 \mathrm{~mm} / \mathrm{d}( \pm 1.0)$ at $25^{\circ} \mathrm{C}$. Optimal growth at $25^{\circ} \mathrm{C}$. No growth observed at $5^{\circ} \mathrm{C}$ and $35^{\circ} \mathrm{C}$.

Type material: RUSSIA, Lisino-Korpus, from Pityogenes chalcographus infesting Pinus sylvestris, February 2006, R. Linnakoski, holotype TUR 205578 (dried culture obtained from 
cross between CMW $23115 \times$ CMW 23118), culture ex-type CBS 141081 = CMW 23115; RUSSIA, Lisino-Korpus, from Pityogenes chalcographus infesting Picea abies, February 2006, $R$. Linnakoski, paratype TUR 205579, culture ex-paratype CBS 141082 = CMW 23116; RUSSIA, Lisino-Korpus, from Picea abies infested with Ips typographus, February 2006, $R$. Linnakoski, paratype TUR 205580, culture ex-paratype CBS 141085 = CMW 23120.

Other specimens examined: RUSSIA, Lisino-Korpus, from Pityogenes chalcographus infesting Pinus sylvestris, February 2006, R. Linnakoski, culture CBS 141084 = CMW 23118

Host trees: Picea abies*, Pinus sylvestris*

Insect vectors: Ips amitinus*, Ips duplicatus*, Ips typographus*, Pityogenes chalcographus*

Known distribution: Czech Republic*, Estonia*, Finland*, Poland*, Russian Karelia*

Notes: Isolates of this species were previously treated as O. brunneo-ciliatum in the Ophiostoma ips complex by Linnakoski et al. (2010). It is probable that this taxon was also treated as O. ainoae or O. brunneo-ciliatum in earlier publications (e.g., Kirisits et al. 2000; Jankowiak 2005; Jankowiak et al. 2009; Repe et al. 2013). In an unpublished study of fungi associated with I. amitinus in Finland and Estonia more than half of the individuals were carrying a fungus tentatively named $O$. ainoae (H. Solheim, unpublished data). Two isolates from this survey that were included in the present study were both O. macroclavatum.

Ophiostoma pseudocatenulatum Jankowiak, R. Linnakoski \& Z.W. De Beer, sp. nov. MB 816638. Fig. 11.

Etymology: The specific epithet refers to the ascospores that often accumulate in a formation resembling a chain.

Sexual state often produced on wood when the two mating types are paired on MEA with sterilised larch twigs (Fig. 11a), rarely produced on MEA. Ascomata superficial on media (Fig. 11b), bases dark, globose, (155-)202-256(-279) $\mu \mathrm{m}$ diam, sparsely ornamented with brown hyphal hairs (11-)15-55(-11) $\mu \mathrm{m}$ long, $0.5-1.5 \mu \mathrm{m}$ wide at the apex, 1.5-2.5 $\mu \mathrm{m}$ wide at the base, necks black, straight or slightly curved, (442-)599-859(-1064) $\mu \mathrm{m}$ long, (30-)35-54(77) $\mu \mathrm{m}$ wide at the base, (12-)14-19(-25) $\mu \mathrm{m}$ wide at the apex. Ostiolar hyphae absent or present (Fig. 10c), light brown with lighter and blunt apex, spirally coiled, aseptate, (3-)9-14($15)$ in number, (16-)25-42(-55) $\mu \mathrm{m}$ long, (1-)1.5-2.5(-3) $\mu \mathrm{m}$ wide at the base, $(0.5-) 0.5-1(-$ 
1.5) $\mu \mathrm{m}$ wide at the apex. Asci not observed. Ascospores one-celled, cylindrical or ovoid (when ascospores have a hyaline sheath) in side view, straight, $(3-) 3.5-4(-5) \times(1-) 1.5-2(-2) \mu \mathrm{m}$, sometimes with hyaline sheath, 0.5-1 $\mu \mathrm{m}$ thick, released from neck in chains (Fig. 11d). Conidiophores macronematous, synnematous, pesotum-like, aggregated in small groups resembling sporodochia (Fig. 11e-f), hyaline, stalk bases rarely pale brown, (1366-)19313696(-4534) $\mu \mathrm{m}$ long including capitulum, (18-)58-144(-320) $\mu \mathrm{m}$ wide at the base; conidiophore heads (124-)178-948(-1641) $\mu \mathrm{m}$ wide, composed of brush-like masses of hyphae. Conidiogenous cells $(13-) 17-22(-46) \times 0.5-1.5 \mu \mathrm{m}$; conidia hyaline, one-celled, cylindrical, (3.5-)4.5-7(-9.5) $\times(0.5) 1-1.5(-2) \mu \mathrm{m}($ Fig. 10g-h), aggregating into a creamcolored mucilaginous mass surrounding the conidiophore heads (Fig. 11e). Synnematal anamorph rare on malt extract agar, more commonly produced on agar with larch twigs. Hyalorhinocladiella-like micronematal asexual state present (Fig 11i). Conidiogenous cells arising directly from hyphae, (7-)11-21(-26) × 1-1.5) $\mu \mathrm{m}$; conidia hyaline, cylindrical, obovate, 4-5.5 (-7) $\times 1-1.5(-2) \mu \mathrm{m}$ (Fig. 10j). Culture characteristics: Colonies on $2 \%$ MEA first hyaline, later becoming olivaceous gray (Fig. 11k), mycelium superficial on agar, aerial mycelium quite abundant, floccose. Growth rates $5.8 \mathrm{~mm} / \mathrm{d}( \pm 0.8)$ at $20^{\circ} \mathrm{C}$ and $8.0 \mathrm{~mm} / \mathrm{d}( \pm$ $0.9)$ at $25^{\circ} \mathrm{C}$. Optimal growth at $30^{\circ} \mathrm{C}(8.1 \mathrm{~mm} / \mathrm{d} ; \pm 1.0)$. Growth observed at $5^{\circ} \mathrm{C}(1.3 \mathrm{~mm} / \mathrm{d})$ and $35^{\circ} \mathrm{C}(4.4 \mathrm{~mm} / \mathrm{d})$.

Type material: POLAND, Rudziniec, from galleries of Ips cembrae infesting Larix decidua, 26 June 2014, R. Jankowiak, holotype TUR 205581 (dried culture obtained from cross between CMW $43103 \times$ CMW 43106), culture ex-type CBS $141276=$ CMW 43103; POLAND, Rudziniec, from adult Ips cembrae infesting Larix decidua, 26 June 2014, R. Jankowiak, paratype TUR 205582, culture ex-type CMW 43097; POLAND, Rudziniec, from galleries of Ips amitinus infesting Larix decidua, 17 June 2014, R. Jankowiak, paratype TUR 205583, culture ex-type CBS $141278=$ CMW 43106.

\section{Host tree: Larix decidua*}

Insect vectors: Ips amitinus*, Ips cembrae*

\section{Known distribution: Austria*, Czech Republic*, Poland*, Scotland*}

Notes: Isolates of this species were recognised as O. brunneo-ciliatum in previous publications (Kirisits et al. 2000; Stauffer et al. 2001; Jankowiak et al. 2007; Linnakoski et al. 2010; Villari 2012; Villari et al. 2013). This fungus (and not O. brunneo-ciliatum) is likely the most frequent fungal associate of the larch bark beetle I. cembrae (Kirisits et al. 2000; Stauffer et al. 2001; 
Jankowiak et al. 2007); however, O. brunneo-ciliatum has also been confirmed in association with this insect (see above). It is likely that isolates from I. amitinus in previous studies (Kirisits et al. 2000; Jankowiak et al. 2009; Repe et al. 2013) also represent this fungus or/and O. macroclavatum (see above).

Ophiostoma tapionis Linnakoski, Z.W. De Beer \& M.J. Wingf., Persoonia 25:84 (2010). MB 518882.

Descriptions: Linnakoski et al. (2010)

Phylogenetic data: Linnakoski et al. (2010); De Beer and Wingfield (2013)

Original reports in literature: Linnakoski et al. (2010)*

Type material: FINLAND, Southern Savonia, Punkaharju, from Hylurgops palliatus infesting Picea abies, February 2006, R. Linnakoski, holotype KUO 021872, culture exholotype CBS 128120 = CMW 23265; FINLAND, Southern Savonia, Punkaharju, from Hylastes brunneus infesting Pinus sylvestris, February 2006, R. Linnakoski, paratype KUO 021873, culture ex-paratype CBS 128122 = CMW 23266; RUSSIA, Lisino-Korpus, from Hylurgops palliatus infesting Pinus sylvestris, February 2006, R. Linnakoski, paratype KUO 021875, culture ex-paratype CBS 128121 = CMW 23269.

Host trees: Picea abies*, Pinus sylvestris*

Insect vectors: Hylastes brunneus*, Hylastes cunicularius*, Hylurgops palliatus*, Ips typographus*, Pityogenes chalcographus*, Tomicus minor*

Known distribution: Finland*, Norway, Poland*, Russian Karelia*

Notes: Only a hyalorhinocladiella-like asexual state is currently known for this fungus. In the original description, isolates of this species were recognised as members of the Ophiostoma ips complex (Linnakoski et al. 2010). This species has been recently found as an associate of H. palliatus in Norway (H. Solheim, unpublished data) and Hylastes cunicularius in Poland (R. Jankowiak, unpublished data). 


\section{DISCUSSION}

Results of this study provide robust support for a newly recognised and phylogenetically clearly defined complex in Ophiostoma sensu stricto. The O. clavatum complex defined here currently accommodates seven morphologically similar species. The species boundaries in the complex are redefined and descriptions have been provided for three new Ophiostoma species. Lectotypes and epitypes have also been designated for O. clavatum and O. brunneo-ciliatum.

Species assigned to the O. clavatum complex share several similarities that distinguish them from the other species within Ophiostoma s. str. (De Beer and Wingfield 2013). The oldest known species in the complex, O. clavatum, together with four other species that have known sexual stages (O. ainoae, O.brunneo-ciliatum, O.macroclavatum sp. nov. and O. pseudocatenulatum sp. nov.), are characterised by brown, spirally coiled ostiolar hyphae and cylindrical to rectangular ascospores, sometimes covered by a thin sheath. The asexual stages of these species range from mononematous hyalorhinocladiella- to synnematous pesotum-like forms. The pesotum-like conidiophores represent two different types: synnematous conidiophores of $O$. ainoae are more similar to e.g. those of $O$. ulmi (Upadhyay 1981; De Beer and Wingfield 2013), and large synnematous, clavate, 'brush-like' conidiomata are found in O. brunneo-ciliatum, O. clavatum, O. macroclavatum sp. nov. and $O$. pseudocatenulatum sp. nov. These are unique morphological characteristics not known to occur in other species in Ophiostoma s. str. The full-grown cultures in agar plates are typically darkly pigmented. However, cultures lose their pigmentation over time when they are sub-cultured. All species in the complex are associates of conifer-infesting bark beetles, most notably of beetles in the genus Ips.

Results of this study confirmed the identity of O. clavatum isolates collected from I. acuminatus infesting P. sylvestris in Europe. It appears that the fungus has a relatively specific association with this bark beetle species and its host tree. This apparently strict association has also been reported in several previous studies (Mathiesen 1950, 1951; Rennerfelt 1950; Mathiesen-Käärik 1953; Francke-Grosmann 1952, 1963a; Käärik 1975a, 1980; Villari 2012; Villari et al. 2013). Although the majority of publications support the view that $O$. clavatum is the primary associate of $I$. acuminatus, some of the previous reports of fungi associated with this beetle species raise questions. For example, an isolate collected from I. acuminatus (CMW 37988) that had previously been treated as O. brunneo-ciliatum (Lieutier et al. 1991; Guérard et al. 2000) was identified as O. clavatum in the present study. This finding most likely excludes the association of O. brunneo-ciliatum with I. acuminatus. Although O. clavatum has been reported from other pine-infesting bark beetles (Käärik 1973, 1975a) as 
well as from spruce (Käärik 1980), no material was available from these studies. We could thus not confirm an association between $O$. clavatum and other bark beetles or host trees.

Ophiostoma brunneo-ciliatum was originally isolated from P. sylvestris infested by I. sexdentatus in Sweden (Mathiesen-Käärik 1953). Unfortunately, recently collected isolates are not available from the same vector beetle and tree host in the same geographic area where the first collections of the fungus were made. At the time of Mathiesen-Käärik's (1953) study, I. sexdentatus was a common bark beetle in Sweden (Voolma et al. 2004). However, reports of I. sexdentatus in Nordic countries have declined in recent decades, and the beetle is currently included in the national Red Lists in Finland, Norway and Sweden (ArtDatabanken 2015; Kålås et al. 2010; Rassi et al. 2010). Based on the present study, isolates identified as O. brunneociliatum are found in association with I. sexdentatus infesting P. sylvestris and I. cembrae infesting L. decidua. This observation is consistent with previous studies, in which the fungus has been reported from I. sexdentatus infesting Pinus spp. (Mathiesen-Käärik 1953, 1960; Lieutier et al. 1989, 1991; Bueno et al. 2010; Jankowiak 2012) as well from I. cembrae infesting L. decidua in Europe (Kirisits et al. 2000; Stauffer et al. 2001; Jankowiak et al. 2007). However, O. brunneo-ciliatum appears to be a frequent associate of mainly I. sexdentatus, while I. cembrae most likely vectors this species only occasionally, and O. pseudocatenulatum may be the dominant fungus associated with the latter insect.

There have been numerous previous reports of O. brunneo-ciliatum in Europe, suggesting that the fungus is associated with various different bark beetles and host trees (Lieutier et al. 1989, 1991; Kirisits et al. 2000; Kirisits 2001, 2004; Bueno et al. 2010; Stauffer et al. 2001; Jankowiak et al. 2007, 2009; Linnakoski et al. 2010; Linnakoski 2011; Jankowiak 2012; Repe et al. 2013). For this reason, we re-examined some isolates from our previous studies identified as O. brunneo-ciliatum (Linnakoski et al. 2010; Linnakoski 2011; Villari et al. 2013; R. Jankowiak, B. Strzałka and B. Kacprzyk 2014, unpublished data). The multigene phylogenetic analyses provided robust evidence that none of these isolates represent O. brunneo-ciliatum. Although morphological characteristics and ecology overlap, substantial differences in phylogenetic data clearly supports the treatment of these isolates as novel species, described here as $O$. brunneolum sp. nov., $O$. macroclavatum sp. nov. and $O$. pseudocatenulatum sp. nov.

Ophiostoma brunneolum was found in association with I. typographus and I. duplicatus in Russia and the Czech Republic. Only the hyalorhinocladiella-like asexual stage of this fungus is currently known. This species appears to be relatively rare in the investigated habitats, at least in comparison to O. macroclavatum. Ophiostoma macroclavatum differs from the other species in the complex by its apparently wider occurrence in association with several spruce- and pine- 
infesting bark beetles, and also based on its morphological characteristics. The most distinct feature of O. macroclavatum is its exceptionally large pesotum-like conidiomata. The third novel species, $O$. pseudocatenulatum, has a distinct ecology as an associate of the bark beetles I. cembrae and I. amitinus on L. decidua in Europe. Unlike the other novel species, O. pseudocatenulatum has ascospores that emerge from perithecial necks in chains. In addition, it has a substantially more rapid growth on MEA and a higher optimal temperature for growth in culture than any other species in the $O$. clavatum complex. These features may be connected to the ecology of L. decidua. As a light-demanding tree species, L. decidua often colonizes disturbed forest sites and open land, and is exposed to strong solar insolation. For this reason, fungal associates of bark beetles infesting larch would need to be able to colonize strongly heated sapwood and phloem of trees.

Identification of species residing in the $O$. clavatum complex has previously relied strongly on morphological characteristics but more recently on sequence data for the ITS region. Results of the present study show that reliable delimitation of these cryptic species requires multigene DNA sequence data and phylogenetic analyses. Of the four gene regions used in this study, only the ITS data failed to provide sufficient resolution for species delineation within the $O$. clavatum complex. Therefore, ITS sequence data should be used with caution for species level identification purposes. Furthermore, isolates of species identified in previous studies could be the same as the novel cryptic taxa described here, or they could represent additional novel species in the $O$. clavatum complex. In line with other investigations delineating cryptic species within the ophiostomatoid fungi, the present study implies that the species in the O. clavatum complex are more specifically associated with particular bark beetles than has been recognised previously, suggesting close co-evolution between the insects and their specific fungal associates.

Very little is known regarding potential pathogenicity of the species residing in the O. clavatum complex. The species have generally been considered as weak or non-aggressive pathogens that cause rapidly spreading blue-stain in sapwood of P. sylvestris (Mathiesen 1951; Käärik 1980; Lieutier et al. 1991; Guérard et al. 2000). However, there is evidence that some of these fungi might be involved in exhausting their host plant defenses (Lieutier et al. 1991; Guérard et al. 2000; Villari et al. 2012). The large number of recently emerging and severe outbreaks of beetles vectoring species in this complex suggests that these fungi could become increasingly important as agents of blue-stain or forest pathogens. This underpins the need for correct identification of these fungi, and further studies are clearly required to better understand their distribution, ecology and pathogenicity. 


\section{Acknowledgements}

We thank Stefan Ekman and Anders Nording at the Museum of Evolution, University of Uppsala, for providing facilities and their help to study the UPS herbarium specimens. The Nikon microscope and SEM images were taken at the School of Forest Sciences and at the Department of Physics and Mathematics, University of Eastern Finland, respectively. We acknowledge Ari Pappinen, Pertti Pääkkönen and Tommi Itkonen for providing facilities and their help to conduct the above mentioned microscopy. An isolate previously identified as O. brunneo-ciliatum was obtained as a kind concession of Francois Lieutier and Annie Yart, Institut National de la Recherche Agronomique (INRA), Orleans, France. Gernot Hoch at the Federal Research and Training Centre for Forest, Natural Hazards and Landscape, Vienna, kindly provided pine material infested by I. acuminatus in Southern Austria, from which O. clavatum was isolated. Specifically acknowledged is also Johanna Ahtiainen, who collected many isolates investigated in this study. We are most grateful for our numerous colleagues, laboratory technicians and assistants for their invaluable help with isolating and maintaining the fungal cultures used in this study. We also thank the three anonymous reviewers whose comments helped improving this article. The study was supported financially by the University of Helsinki and the Emil Aaltonen Foundation, Finland; the University of Pretoria, the members of the Tree Protection Co-operative Programme (TPCP) and the THRIP initiative of the Department of Trade and Industry, South Africa; the Ministry of Science and Higher Education of the Republic of Poland; Ministero dell'Istruzione, dell'Università e della Ricerca (PRIN 200774ENMR 'Climatic change and Italian pine pests: a model study'), Italy; the European Union's Seventh Framework Programme FP7/2007-2013 (KBBE 2009-3) under grant agreement 245268 ISEFOR; and the Norwegian Biodiversity Information Centre (pnr. 70184233).

\section{REFERENCES}

Altenkirch W, Majunke C, Ohnesorge B (2002) Waldschutz auf ökologischer Grundlage. Verlag Eugen Ulmer, Stuttgart, Germany

Aoshima K (1965) Studies on wood-staining fungi of Japan. Dissertation, University of Tokyo [in Japanese]

ArtDatabanken (2015) Rödlista 2010. ArtDatabanken, SLU, Uppsala, Sweden. Available from http://www.slu.se/artdatabanken (accessed April 2015) [in Swedish]

Ariyawansa HA, Hawksworth DL, Hyde KD, Jones EBG, Maharachchikumbura SSN, Manamgoda DS, Thambugala KM, Udayanga D, Camporesi E, Daranagama A, Jayawardena R, Liu J-K, McKenzie EHC, Phookamsak R, Senanayake IC, Shivas RG, Tian Q, Xu JC (2014) Epitypification and neotypification: guidelines with appropriate and inappropriate examples. Fungal Divers 69:5791

Bueno A, Diez JJ, Fernández MM (2010) Ophiostomatoid fungi transported by Ips sexdentatus (Coleoptera; Scolytidae) in Pinus pinaster in NW Spain. Silva Fenn 44:387-397

Carbone I, Kohn LM (1999) A method for designing primer sets for speciation studies in filamentous ascomycetes. Mycologia 91:553-556 
Colombari F, Battisti A, Schroeder LM, Faccoli M (2012) Life-history traits promoting outbreaks of the pine bark beetle Ips acuminatus (Coleoptera: Curculionidae, Scolytinae) in the south-eastern Alps. Eur J Forest Res 3:553-561. doi:10.1007/s10342-011-0528-y

Colombari F, Schroeder M, Battisti A, Faccoli M (2013). Spatio-temporal dynamics of Ips acuminatus outbreak and implications for management. Agr Forest Entomol 15:34-42. doi:10.1111/j.14619563.2012.00589.x

De Beer ZW, Seifert KA, Wingfield MJ (2013) A nomenclator for ophiostomatoid genera and species in the Ophiostomatales and Microascales. In: Seifert KA, De Beer ZE, Wingfield MJ (eds) Ophiostomatoid fungi: expanding frontiers. CBS Biodiv Ser 12:261-268

De Beer ZW, Wingfield MJ (2013) Emerging lineages in the Ophiostomatales: In: Seifert KA, De Beer ZE, Wingfield MJ (eds) Ophiostomatoid fungi: expanding frontiers. CBS Biodiv Ser 12:2146

Dobbertin M, Wermelinger B, Bigler C, Bürgi M, Carron M, Foster B, Gimmi U, Rigling M (2007) Linking increasing drought stress to Scots pine mortality and bark beetle infestations. Sci World J 7:231-239. doi:10.1100/tsw.2007.58

Duong TA, De Beer ZW, Wingfield BD, Wingfield MJ (2012) Phylogeny and taxonomy of species in the Grosmannia serpens complex. Mycologia 104:715-732. doi:10.385/11-109

Francke-Grosmann H (1952) Über die Ambrosiazucht der beiden Kiefernborkenkäfer Myelophilus minor Htg. und Ips acuminatus Gyll. Medd Statens Skogsforskningsinst 41:1-52

Francke-Grosmann H (1963a) Die Übertragung der Pilzflora bei dem Borkenkäfer Ips acuminatus Gyll.: Ein Beitrag zur Kenntnis der Ipiden-Symbiosen. Z Angew Entomol 52:355-361

Francke-Grosmann H (1963b) Some new aspects in forest entomology. Ann Rev Entomol 8:415-438

Gardes M, Bruns TD (1993) ITS primers with enhanced specificity for Basidiomycetes - application to the identification of mycorrhiza and rusts. Mol Ecol 2:113-118

Gebhardt H, Weiss M, Oberwinkler F (2005) Dryadomyces amasae: a nutritional fungus associated with ambrosia beetles of the genus Amasa (Coleoptera: Curculionidae, Scolytinae). Mycol Res 109:687-696

Glass NL, Donaldson GC (1995) Development of primer sets designed for use with the PCR to amplify conserved genes from filamentous Ascomycetes. Appl Environ Microbiol 61:1323-1330

Grobbelaar J, de Beer ZW, Bloomer P, Wingfield MJ, Wingfield BD (2010) Ophiostoma tsotsi sp. nov., a wound- infesting fungus of hardwood trees in Africa. Mycopathol 169:413-423. doi:10.1007/s11046-009-9267-8

Grubelnik RJ (1998) Untersuchungen über die Zusammensetzung der Mycoflora von Ips typographus L. auf ausgewählten Wald-Standorten unter besonderer Berücksichtigung der pathogenen Art Ceratocystis polonica. Master/Diploma Thesis, Universität für Bodenkultur Wien (BOKU)

Guérard N, Dreyer E, Lieutier F (2000) Interactions between Scots pine, Ips acuminatus (Gyll.) and Ophiostoma brunneo-ciliatum (Math.): estimation of the critical thresholds of attack and 
inoculation densities and effects on hydraulic properties in the stem. Ann For Sci 57:681-690. doi:10.1051/forest:2000149

Harding S (1989) The influence of mutualistic blue-stain fungi on bark beetle population dynamics. Dissertation, Royal Veterinary and Agricultural University Copenhagen

Hausner G, Reid J (2003) Notes on Ceratocystis brunnea and some other Ophiostoma species based on partial ribosomal DNA sequence analysis. Can J Bot 81:865-876. doi:10.1139/b03-080

Hunt J (1956) Taxonomy of the genus Ceratocystis. Lloydia 19:1-59

Jacobs K, Bergdahl DR, Wingfield MJ, Halik S, Seifert KA, Bright DE, Wingfield BD (2004) Leptographium wingfieldii introduced into North America and found associated with exotic Tomicus piniperda and native bark beetles. Mycol Res 108:411-418. doi:10.1017/S0953756204009748

Jankowiak R (2004) Ophiostomatoid fungi associated with the spruce bark beetle (Ips typographus) new for Poland: occurrence and morphology. Phytopathol Pol 33:5-21

Jankowiak R (2005) Fungi associated with Ips typographus on Picea abies in southern Poland and their succession into the phloem and sapwood of beetle-infested trees and logs. Forest Pathol $35: 37-55$

Jankowiak R (2012) Ophiostomatoid fungi associated with Ips sexdentatus on Pinus sylvestris in Poland. Dendrobiology 68:43-54

Jankowiak R, Kot M (2011) Ophiostomatoid fungi associated with bark beetles (Coleoptera: Scolytidae) colonizing branches of Pinus sylvestris in Southern Poland. Pol Bot J 56:287-293

Jankowiak R, Rossa R, Místa K (2007) Survey of fungal species vectored by Ips cembrae to European larch trees in Raciborskie forests (Poland). Czech Mycol 59:227-239

Jankowiak R, Kacprzyk M, Młynarczyk M (2009) Diversity of ophiostomatoid fungi associated with bark beetles (Coleoptera: Scolytidae) colonizing branches of Norway spruce (Picea abies) in southern Poland. Biologia 64:1170-1177. doi:10.2478/s11756-009-0188-2

Katoh K, Standley D (2013) MAFFT multiple sequence alignment software version 7: improvements in performance and usability. Mol Biol Evol 30:772-780. doi:10.1093/molbev/mst010

Kirisits T (2001) Studies on the association of ophiostomatoid fungi with bark beetles in Austria with special emphasis on Ips typographus and Ips cembrae and their associated fungi Ceratocystis polonica and Ceratocystis laricicola. Dissertation, Universität für Bodenkultur Wien (BOKU)

Kirisits T (2004) Fungal associates of European bark beetles with emphasis on the Ophiostomatoid fungi. In: Lieutier F, Day KR, Battisti A, Grégoire J-C, Evans H (eds) Bark and wood boring insects in living trees in Europe, a synthesis. Kluwer Academic Publishers, Dordrecht, pp 181-235

Kirisits T (2010) Fungi isolated from Picea abies infested by the bark beetle Ips typographus in the Białowieża forest in north-eastern Poland. Forest Pathol 40:100-110. doi:10.1111/j.14390329.2009.00613.x 
Kirisits T (2013) Dutch elm disease and other Ophiostoma diseases. In: Gonthier P, Nicolotti, G (eds) Infectious forest diseases. CABI, Wallingford, pp 256-282

Kirisits T, Grubelnik R, Führer E (2000) Die ökologische Bedeutung von Bläuepilzen für rindenbrütende Borkenkäfer. In: Müller F (ed) Mariabrunner Waldbautage 1999. Umbau sekundärer Nadelwälder. FBVA- Berichte, Schriftenreihe der Forstlichen Bundesversuchsanstalt, Wien 111, pp 117-137. http://bfw.ac.at/040/pdf/1348_02.pdf (accessed November 2015)

Kirisits T, Konrad H, Wingfield MJ, Chhetri DB (2013) Ophiostomatoid fungi associated with the Eastern Himalayan spruce bark beetle, Ips schmutzenhoferi, in Bhutan and their pathogenicity to Picea spinulosa and Pinus wallichiana. In: Seifert KA, De Beer ZE, Wingfield MJ (eds) Ophiostomatoid fungi: expanding frontiers. CBS Biodiv Ser 12:99-112

Kirschner R (1998) Diversität mit Borkenkäfern azzoziierter filamentöser Mikropilze. Dissertation, Eberhard-Karls-Universtität, Tübingen

Kirschner R (2001) Diversity of filamentous fungi in bark beetle galleries in Central Europe. In: Misra JK, Horn BW (eds) Trichomyces and other fungal groups. Robert W. Lichtwardt Commemoration Volume. Science Publishers, Inc, Enfield, Plymouth, pp 175-196

Kålås J, Viken Å, Henriksen S, Skjelseth S. (eds) (2010). The 2010 Norwegian Red List for Species. Norwegian Biodiversity Information Centre, Norway

Käärik A (1973) The succession of blueing fungi in insect galleries in roundwood during storage. Research Note No R 83. Royal Coll. For. Dep. Forest Products, Stockholm, Sweden, pp 1-20 Käärik A (1975a) Insekter och blånad. Uppsatser/Sveriges Lantbruksuniversitet, Institutionen för Virkeslära, 0349-8913; 54 Skogs- och Virkesskydd: 170-187

Käärik A (1975b) Succession of microorganisms during wood decay. In: Biological transformation of wood by microorganisms. In: Liese W (ed) Proceedings of the Sessions on Wood Products Pathology at the 2nd International Congress of Plant Pathology, 10-12 September 1973, Minneapolis, USA. Springer-Verlag, Berlin, pp 39-51

Käärik, A (1980) Fungi causing sap stain in wood. The Swedish University of Agricultural Sciences, Department of Forest Products. Report Nr R 114

Krehan H (2011) Borkenkäferprobleme bei Kiefern in einem Steinschlagschutzwald in Kärnten.

Forstschutz Aktuell 53:2-4. http://bfw.ac.at/400/pdf/fsaktuell_53_1.pdf (accessed November 2015) Lieutier F, Yart A, Garcia J, Ham MC, Morelet M, Levieux J (1989) Champignons phytopathogènes associés à deux coléeoptères scolytidae du pin sylvestre (Pinus sylvestris L.) et étude préliminaire de leur agressivité envers l'hote. Ann Sci For 46:201-216

Lieutier F, Garcia J, Yart A, Vouland G, Pettinetti M, Morelet M (1991) Ophiostomatales (Ascomycetes) associated with Ips acuminatus Gyll. (Coleoptera, Scolytidae) in Scots pine (Pinus sylvestris L.) in South-Eastern France, and comparison with Ips sexdentatus Boern. Agronomie 11:807-817 [in French] 
Linnakoski R (2011) Bark beetle-associated fungi in Fennoscandia with special emphasis on species of Ophiostoma and Grosmannia. Dissertationes Forestales 119. doi:10.14214/df.119

Linnakoski R, De Beer ZW, Rousi M, Solheim H, Wingfield MJ (2009). Ophiostoma denticiliatum sp. nov. and other Ophiostoma species associated with the birch bark beetle in southern Norway. Persoonia 23:9-15. doi:10.3767/003158509X46803

Linnakoski R, De Beer ZW, Rousi M, Niemelä P, Pappinen A, Wingfield MJ (2008) Fungi, including Ophiostoma karelicum sp. nov., associated with Scolytus ratzeburgi infesting birch in Finland and Russia. Mycol Res 112:1475-1488. doi:10.1016/j.mycres.2008.06.007

Linnakoski R, De Beer ZW, Ahtiainen J, Sidorov E, Niemelä P, Pappinen A, Wingfield MJ (2010) Ophiostoma spp. associated with pine- and spruce-infesting bark beetles in Finland and Russia. Persoonia 25:72-93. doi:10.3767/003158510X550845

Marincowitz S, Duong TA, De Beer ZW, Wingfield MJ (2015) Cornuvesica: A little known mycophilic genus with a unique biology and unexpected new species. Fungal Biol 119:615-630. doi:10.1016/j.funbio.2015.03.007

Masuya H, Yamaoka Y, Wingfield MJ (2013). Ophiostomatoid fungi and their associations with bark beetles in Japan. In: Seifert KA, De Beer ZE, Wingfield MJ (eds) Ophiostomatoid fungi: expanding frontiers. CBS Biodiv Ser 12:77-90

Mathiesen A (1950) Über einige mit Borkenkäfern assoziierte Bläuepilze in Schweden. Oikos 2:275308

Mathiesen A (1951) Einige neue Ophiostoma-Arten in Schweden. Sven Bot Tidskr 45:203-232

Mathiesen-Käärik A (1953) Eine Übersicht über die gewöhnlichsten mit Borkenkäfern assoziierten Bläuepilze in Schweden und einige für Schweden neue Bläupilze. Medd Statens Skogsforskningsinst 43:1-74

Mathiesen-Käärik A (1960) Studies on the ecology, taxonomy and physiology of Swedish insectassociated blue stain fungi, especially the genus Ceratocystis. Oikos 11:1-25

Miller MA, Pfeiffer W, Schwartz T (2010) Creating the CIPRES Sciences Gateway for inference of large phylogenetic trees. In: Proceedings of the Gateway Computing Environments Workshop (GCE). New Orleans, LA, USA. November 14, 2010, pp 1-8

Musvuugwa T, De Beer ZW, Duong TA, Dreyer LL, Oberlander KC, Roets F (2015) New species of Ophiostomatales from Scolytinae and Platypodinae beetles in the Cape Floristic Region, including the discovery of the sexual state of Raffaelea. A Van Leeuw J Microb 108:933-950. doi:10.1007/s10482-015-0547-7

Nylander JAA (2004) MrModeltest v.2. Program distributed by the author. Evolutionary Biology Centre, Uppsala University, Sweden

O'Donnel K, Cigelnik E (1997) Two divergent intragenomic rDNA ITS2 types within a monophyletic lineage of the fungus Fusarium are nonorthologous. Mol Phylogenet Evol 7:103-116. doi:10.1006/mpev.1996.0376 
O'Donnell K, Kistler HC, Cigelnik E, Ploetz RC (1998) Multiple evolutionary origins of the fungus causing Panama disease of banana: concordant evidence from nuclear and mitochondrial gene genealogies. PNAS 95:2044-2049

Okada G, Seifert KA, Takematsu A, Yamaoka Y (1998) A molecular phylogenetic reappraisal of the Graphium complex based on 18S rDNA sequences. Can J Bot 76:1495-1506. doi:10.1139/b98-089

Pashenova NV, Vetrova V P, Matrenina RM, Sorokina E N (1995) Ophiostoma fungi in the galleries of the larch bark beetle. Lesovedenie 6:62-68

Pattengale ND, Alipour M, Bininda-Emonds OR, Moret BM, Stamakis A (2010) How many bootstrap replicates are necessary? J Comput Biol 17:337-354. doi:10.1089/cmb.2009.0179

Rassi P, Hyvärinen E, Juslén A, Mannerkoski I. (eds.) (2010) The 2010 Red List of Finnish Species. Ympäristöministeriö \& Suomen ympäristökeskus, Helsinki

Redfern DB, Stoakley JT, Steele H, Minter DW (1987) Dieback and death of larch caused by Ceratocystis laricicola sp. nov. following attack by Ips cembrae. Plant Pathol 36:467-480

Rennerfelt E (1950) Über den Zusammenhang zwischen dem Verblauen des Holzes und den Insekten. Oikos 2:120-137

Repe A, Kirisits T, Piškur, de Groot M, Kump B, Jurc M (2013) Ophiostomatoid fungi associated with three spruce-infesting bark beetles in Slovenia. Ann For Sci 70:717-727. doi:10.1007/s13595-0130311-y

Rebetez M, Dobbertin M (2004) Climate change may already threaten Scots pine stands in the Swiss Alps. Theor Appl Climatol 79:1-9. doi:10.1007/s00704-004-0058-3

Robert V, Vu D, Amor AB, van de Wiele N, Brouwer C, Jabas B, Szoke S, Dridi A, Triki M, Ben Daoud S, Chouchen O, Vaas L, de Cock A, Stalpers JA, Stalpers D, Verkley GJ, Groenewald M, Dos Santos FB, Stegehuis G, Li W, Wu L, Zhang R, Ma J, Zhou M, Gorjon SP, Eurwilaichitr L, Ingsriswang S, Hansen K, Schoch C, Robbertse B, Irinyi L, Meyer W, Cardinali G, Hawksworth DL, Taylor JW, Crous PW (2013). MycoBank gearing up for new horizons. IMA Fungus 4:371379. doi:10.5598/imafungus.2013.04.02.16

Ronquist F, Huelsenbeck JP (2003) MrBayes 3: Bayesian phylogenetic inference under mixed models. Bioinformatics 19:1572-1574. doi:10.1093/bioinformatics/btg180

Sallé A, Monclus R, Yart A, Garcia J, Romary P, Lieutier F (2005) Fungal flora associated with Ips typographus: frequency, virulence, and ability to stimulate the host defence reaction in relation to insect population levels. Can J For Res 35:365-373

Seifert K.A., De Beer Z.W, Wingfield M.J. (eds) (2013) Ophiostomatoid fungi: Expanding frontiers. Utrecht, CBS-KNAW Fungal Biodiversity Centre. CBS Biodiversity Series 12

Siitonen, J. (2014) Ips acuminatus kills pines in southern Finland. Silva Fenn 48: article id 1145. doi:10.14214/sf.1145

Solheim H (1986) Species of Ophiostomataceae isolated from Picea abies infested by the bark beetle Ips typographus. Nord J Bot 6:199-207 
Solheim H (1992) The early stages of fungal invasion in Norway spruce infested by the bark beetle Ips typographus. Can J Bot 70:1-5. doi:10.1139/b92-001

Solheim H (1993) Fungi associated with the spruce bark beetle Ips typographus in an endemic area in Norway. Scan J Forest Res 8:118-122. doi:10.1080/02827589309382760

Stamakis A (2014) RAxML version 8: A tool for phylogenetic analysis and post-analysis of large phylogenies. Bioinformatics 30:1312-1313. doi:10.1093/bioinformatics/btu033

Stamakis A, Hoover P, Rougemont J (2008) A rapid bootstrap algorithm for the RAxML web-servers. Syst Biol 57:758-771. doi:10.1080/10635150802429642

Stauffer C, Kirisits T, Nussbaumer C, Pavlin R, Wingfield MJ (2001) Phylogenetic relationships between the European and Asian eight spined larch bark beetle populations (Coleoptera, Scolytidae) inferred from DNA sequences and fungal associates. Eur J Entomol 98:99-105

Swofford DL (2002) PAUP* 4.0: phylogenetic analysis using parsimony (* and other methods). Sinauer Associates, Sunderland

Tamura K, Stecher G, Peterson D, Filipski A, Kumar S (2013) MEGA6: Molecular Evolutionary Genetics Analysis version 6.0. Mol Biol Evol 30:2725-2729. doi:10.1093/molbev/mst197

Upadhyay HP (1981) A monograph of Ceratocystis and Ceratocystiopsis. The University of Georgia Press, Georgia, USA

Viiri H (1997) Fungal associates of the spruce bark beetle Ips typographus L. (Col. Scolytidae) in relation to different trapping methods. J Appl Entomol 121:529-533

Viiri H, Lieutier F (2004) Ophiostomatoid fungi associated with the spruce bark beetle, Ips typographus, in three areas in France. Ann For Sci 61:1-5

Villari C (2012) Fungi associated with the pine engraver beetle Ips acuminatus and their interactions with the host tree. Dissertation, Dipartimento di Agronomia Animali Alimenti Risorse Naturali e Ambiente, Universita' Degli Studi Di Padova

Villari C, Battisti A, Chakraborty S, Michelozzi M, Bonello P, Faccoli M (2012) Nutritional and pathogenic fungi associated with the pine engraver beetle trigger comparable defenses in Scots pine. Tree Physiol 37:867-879. doi:10.1093/treephys/tps056

Villari C, Tomlinson JA, Battisti A, Boonham N, Capretti P, Massimo F (2013) Use of loop-mediated isothermal amplification for detection of Ophiostoma clavatum, the primary blue stain fungus associated with Ips acuminatus. Appl Environ Microbiol 79:2527-2533. doi:10.1128/AEM.0361212

Voolma K, Mandelshtam MJ, Shcherbakov AN, Yakovlev EB, Õunap H, Süda I, Popovichev BG, Sharapa TV, Galasjeva TV, Khairetdinov RR, Lipatkin VA, Mozolevskaya EG (2004) Distribution and spread of bark beetles (Coleoptera: Scolytidae) around the Gulf of Finland: a comparative study with notes on rare species of Estonia, Finland and North-Western Russia. Entomol Fenn $15: 198-210$ 
Wermelinger B, Rigling A, Schneider Mathis D, Dobbertin M (2008) Assessing the role of bark- and wood-boring insects in the decline of Scots pine (Pinus sylvestris) in the Swiss Rhone valley. Ecol Entomol 33:239-249. doi:10.1111/j.1365-2311.2007.00960.x

White TJ, Bruns T, Lee S, Taylor J (1990) Amplification and direct sequencing of fungal ribosomal RNA genes for phylogenetics. In: Innis MA, Gelfand DH, Sninsky JJ, White TJ (eds) PCR protocols: a guide to methods and applications. Academic Press, San Diego, California, pp 315321

Wingfield M.J., Seifert K.A., Webber J.F. (eds) (1993) Ceratocystis and Ophiostoma: taxonomy, ecology and pathogenicity. APS Press, St Paul, MN

Yamaoka Y, Wingfield MJ, Takahashi I, Solheim H (1997) Ophiostomatoid fungi associated with the spruce bark beetle Ips typographus f. japonicus in Japan. Mycol Res 101:1214-1227

Yamaoka Y, Wingfield MJ, Ohsawa M, Kuroda Y (1998) Ophiostomatoid fungi associated with Ips cembrae in Japan and their pathogenicity to Japanese larch. Mycoscience 39:367-378

Yamaoka Y, Chung W-H, Masuya, H, Hizai, M (2009) Constant association of ophiostomatoid fungi with the bark beetle Ips subelongatus invading Japanese larch logs. Mycoscience 50:165-172

Zipfel RD, De Beer ZW, Jacobs K, Wingfield BD, Wingfield MJ (2006) Multi-gene phylogenies define Ceratocystiopsis and Grosmannia distinct from Ophiostoma. Stud Mycol 55:75-97. doi:10.3114/sim.55.1.133 
Fig. 1 a Exposed galleries of Ips acuminatus on the sapwood surface of Pinus sylvestris and b-c extensive blue-stain development in the sapwood of Pinus sylvestris caused by its fungal associate Ophiostoma clavatum. Scale bars a, c $1 \mathrm{~cm}$

Fig. 2 Phylogenetic tree obtained from ML analyses of the ITS data set. Isolates used for DNA sequencing in this study are printed in bold type. Bootstrap support values above $70 \%$ for ML/MP are presented at the nodes. Posterior probabilities (above $70 \%$ ) obtained from BI are indicated by bold lines at the relevant branching points. $*=$ bootstrap values $<70 \%$. $\mathrm{T}=$ extype isolates. Scale bar = total nucleotide difference between taxa. S. = Sporothrix

Fig. 3 Phylogenetic tree obtained from ML analyses of the $\beta \mathrm{T}$ data set of the Ophiostoma clavatum complex isolates. Isolates used for DNA sequencing in this study are printed in bold type. Bootstrap support values above $70 \%$ for ML/MP are presented at the nodes. Posterior probabilities (above $70 \%$ ) obtained from BI are indicated by bold lines at the relevant branching points. $*$ = bootstrap values $<70 \% . \mathrm{T}=$ ex-type isolates. Scale bar $=$ total nucleotide difference between taxa

Fig. 4 Phylogenetic tree obtained from ML analyses of the TEF-1 $\alpha$ data set of the Ophiostoma clavatum complex isolates. Isolates used for DNA sequencing in this study are printed in bold type. Bootstrap support values above $70 \%$ for ML/MP are presented at the nodes. Posterior probabilities (above $70 \%$ ) obtained from BI are indicated by bold lines at the relevant branching points. $*=$ bootstrap values $<70 \% . \mathrm{T}=$ ex-type isolates. Scale $b a r=$ total nucleotide difference between taxa

Fig. 5 Phylogenetic tree obtained from ML analyses of the CAL data set of the Ophiostoma clavatum complex isolates. Isolates used for DNA sequencing in this study are printed in bold type. Bootstrap support values above $60 \%$ for ML/MP are presented at the nodes. Posterior probabilities (above $60 \%$ ) obtained from BI are indicated by bold lines at the relevant branching points. $*=$ bootstrap values $<60 \%$. T = ex-type isolates. Scale bar $=$ total nucleotide difference between taxa

Fig. 6 Morphological characteristics of the Ophiostoma brunneo-ciliatum lectotype specimen (UPS:BOT:F-130972) (a-c), as well as of structures in the Ips sexdentatus galleries on Pinus sylvestris and living cultures (CMW 39827, CMW 39828, CMW 39842) (d-f). a Ascoma. b 
Spirally coiled, brown ostiolar hyphae. c Rectangular ascospores. d Pesotum-like conidioma (found only in the bark beetle galleries). e. Brush-like conidioma (found only in the bark beetle galleries). f Cultures on MEA. Scale bars $\mathbf{a}, \mathbf{d}-\mathbf{e} 100 \mu \mathrm{m}, \mathbf{b}-\mathbf{c} 10 \mu \mathrm{m}$

Fig. 7 Morphological characteristics of Ophiostoma brunneolum (CMW 23143). a Hyalorhinocladiella-like asexual state. b Conidia. c Culture on MEA. Scale bars $\mathbf{a}-\mathbf{b} 10 \mu \mathrm{m}$

Fig. 8 Morphological characteristics of the lectotype (UPS:BOT:F-130972) of Ophiostoma clavatum (a-c), as well as of living cultures (CMW 37983, CMW 37988) (d-f). a Ascoma. b Spirally coiled, brown ostiolar hyphae. c Rectangular ascospores. d Brush-like conidioma. e Hyalorhinocladiella-like asexual state. f Cultures on MEA. Scale bars $\mathbf{a}, \mathbf{d} 100 \mu \mathrm{m}, \mathbf{b}-\mathbf{c}, \mathbf{e} 10$ $\mu \mathrm{m}$

Fig. 9 Line drawings of Ophiostoma clavatum from Mathiesen (1951, p. 221, Fig. 5c). a Ascoma. b Ascospores. c Brush-like conidioma. d Spirally coiled, brown ostiolar hyphae. e Hyalorhinocladiella-like conidiophore. f conidia. Scale bars a, c $300 \mu \mathrm{m}, \mathbf{b}, \mathbf{f} 10 \mu \mathrm{m}, \mathbf{d} 40 \mu \mathrm{m}$, e $30 \mu \mathrm{m}$.

Fig. 10 Morphological characteristics of Ophiostoma macroclavatum sp. nov. (CMW 23115) a Ascoma formed on spruce twigs (CMW $25115 \times$ CMW 23118). b Rectangular ascospores. c Spirally coiled, brown ostiolar hyphae. d-e Brush-like conidioma. f Conidia. g Hyalorhinocladiella-like conidiophore. h Culture on MEA. Scale bars a, e $100 \mu \mathrm{m}, \mathbf{b}-\mathbf{c} 10 \mu \mathrm{m}$, d $1000 \mu \mathrm{m}, \mathbf{f}-\mathbf{g} 10 \mu \mathrm{m}$

Fig. 11 Morphological characteristics of Ophiostoma pseudocatenulatum sp. nov. (CMW 43103). a Ascoma formed on larch twigs (CMW $43103 \times$ CMW 43106). b Ascoma. c Rectangular ascospores. d. Spirally coiled, brown ostiolar hyphae. e-f Brush-like conidioma. g Conidia. h. Hyalorhinocladiella-like conidiophore and conidia. i Culture on MEA. Scale bars $\mathbf{b}, \mathbf{f} 250 \mu \mathrm{m}, \mathbf{d} 25 \mu \mathrm{m}, \mathbf{c}, \mathbf{g}, \mathbf{h} 10 \mu \mathrm{m}$ 


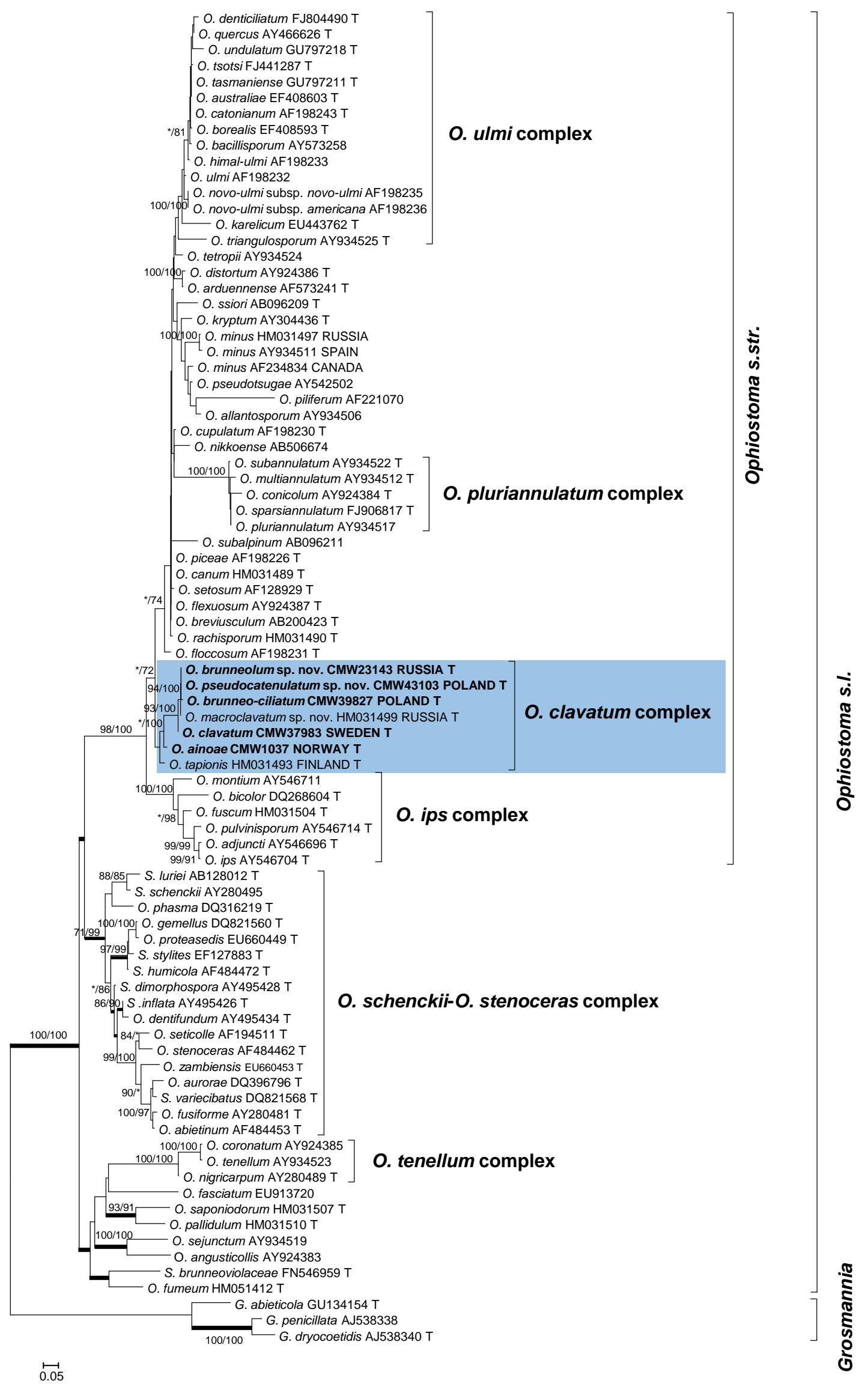




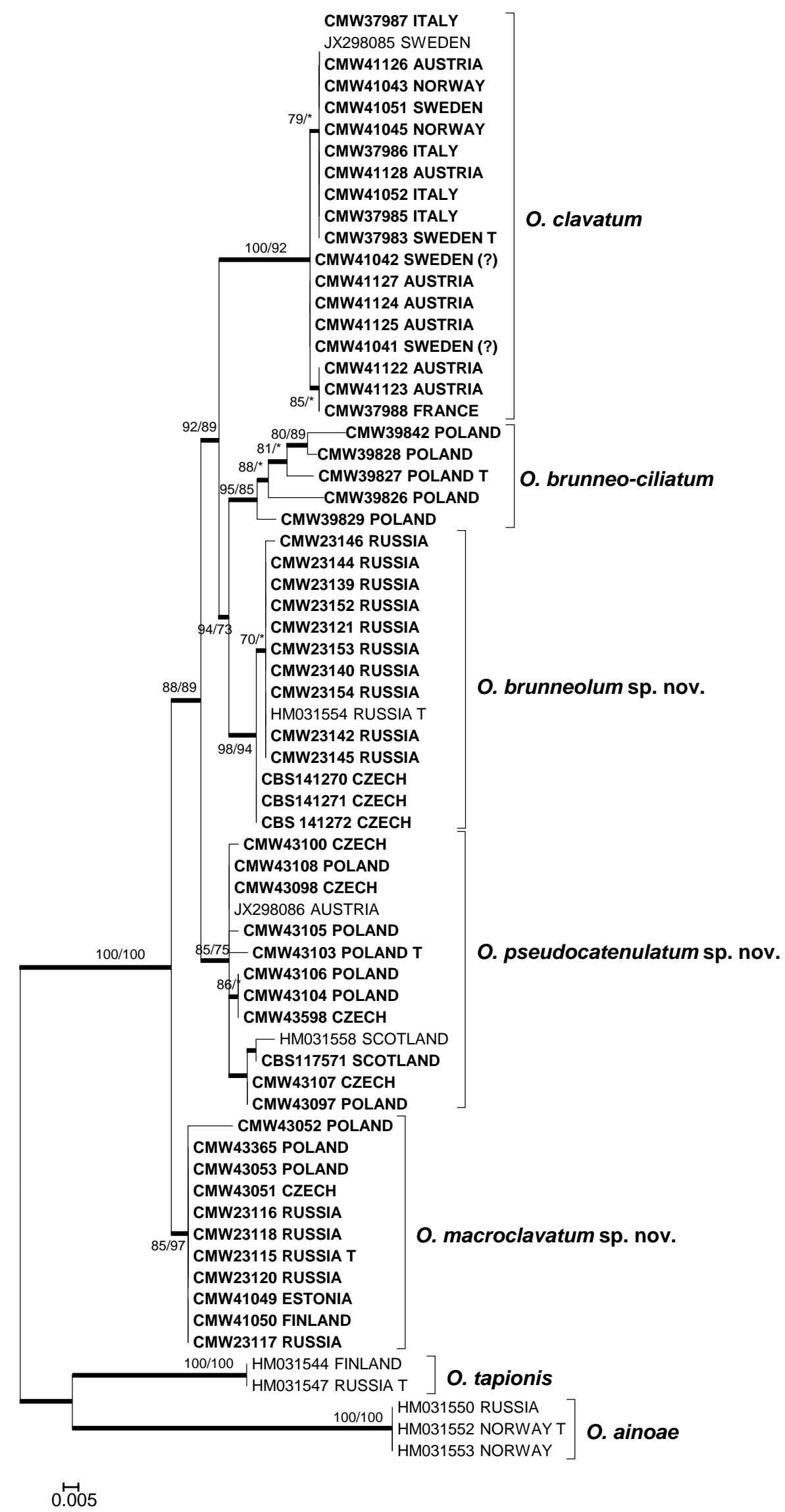




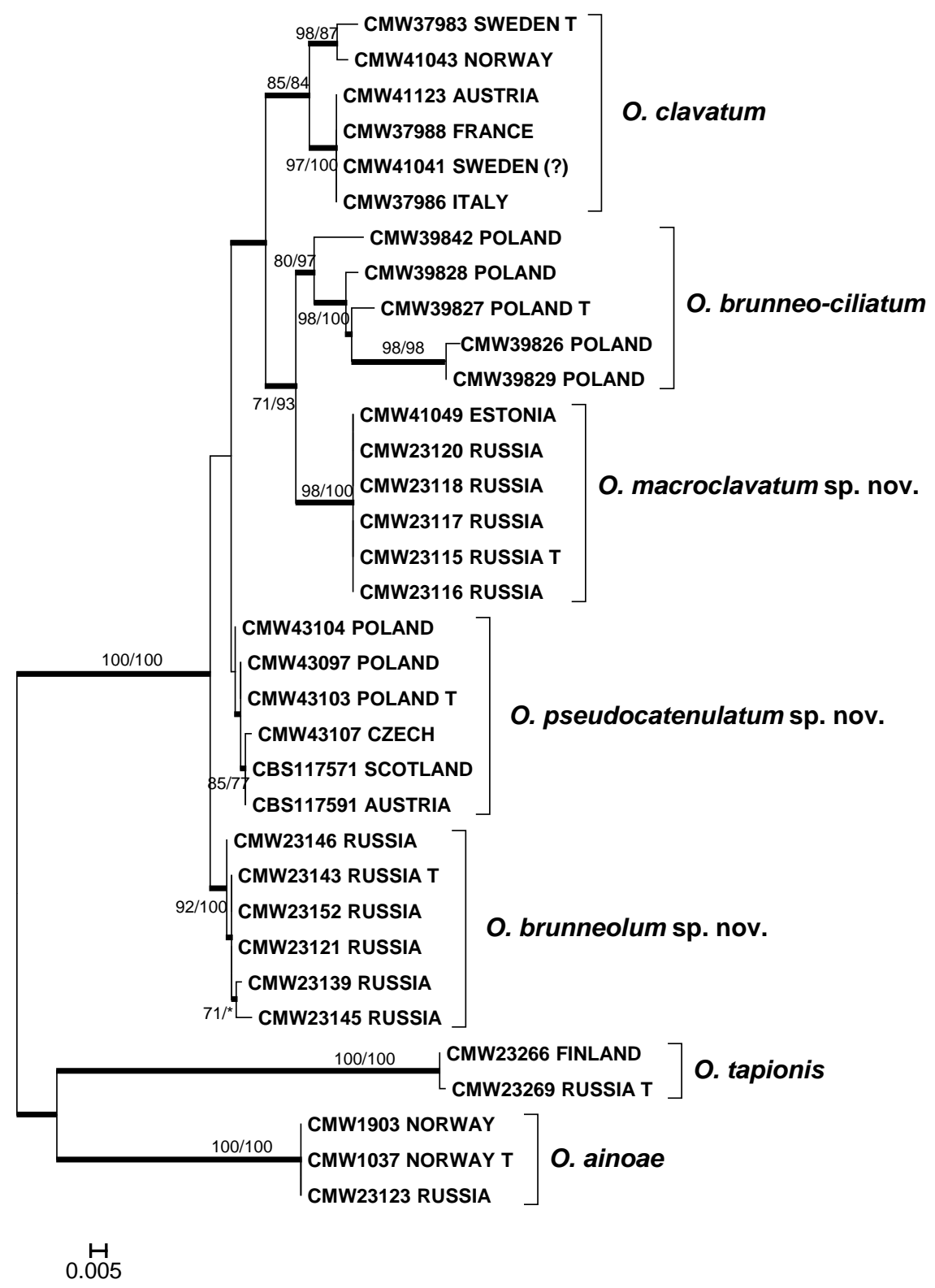




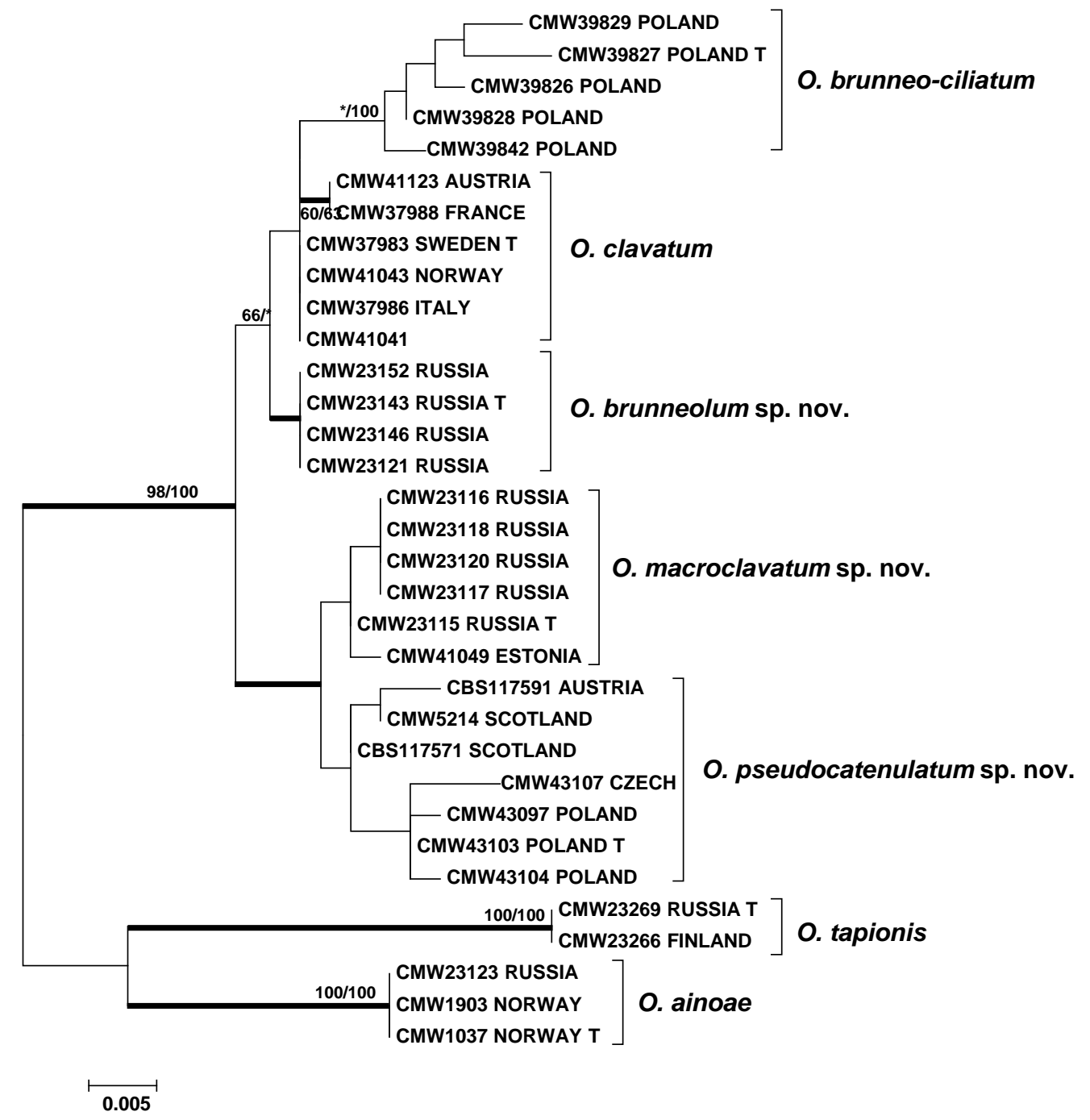



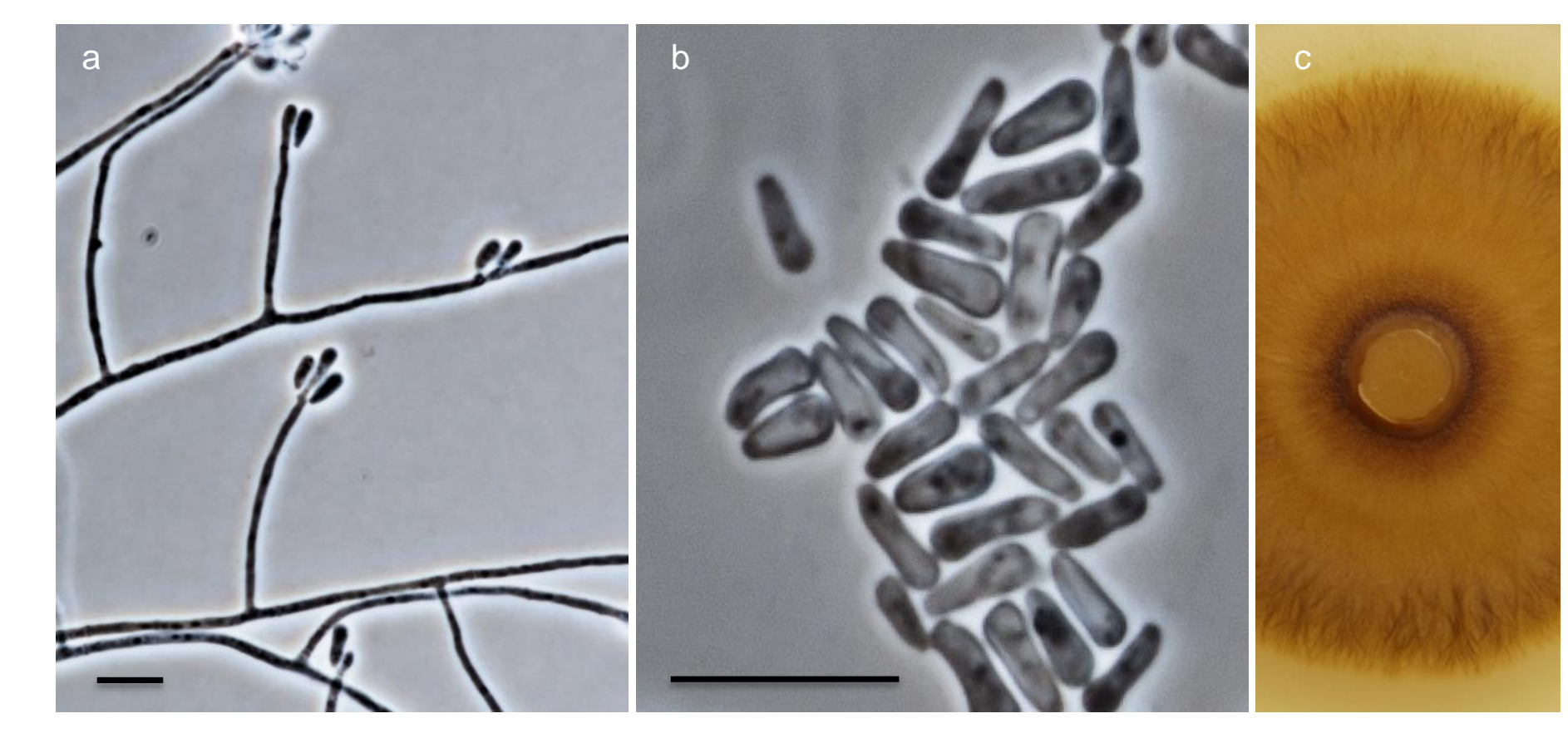

Figure 7 

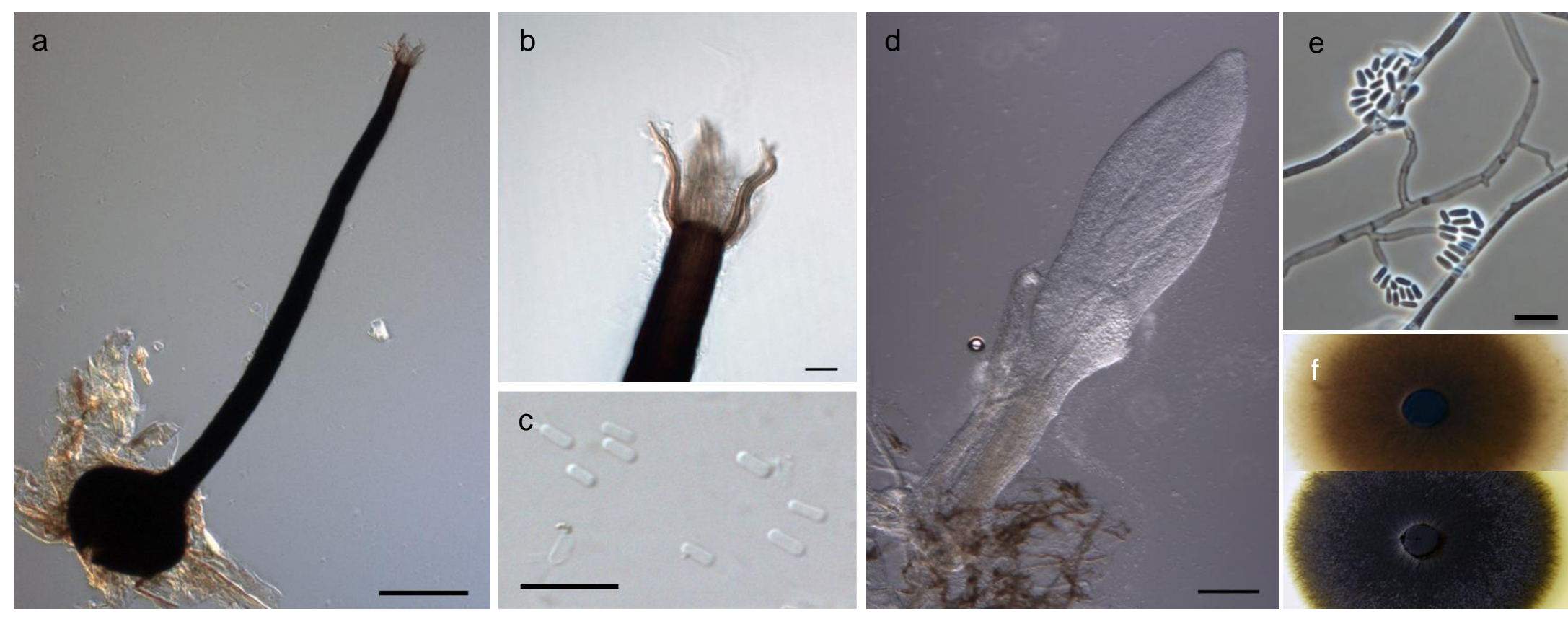

Figure 8 


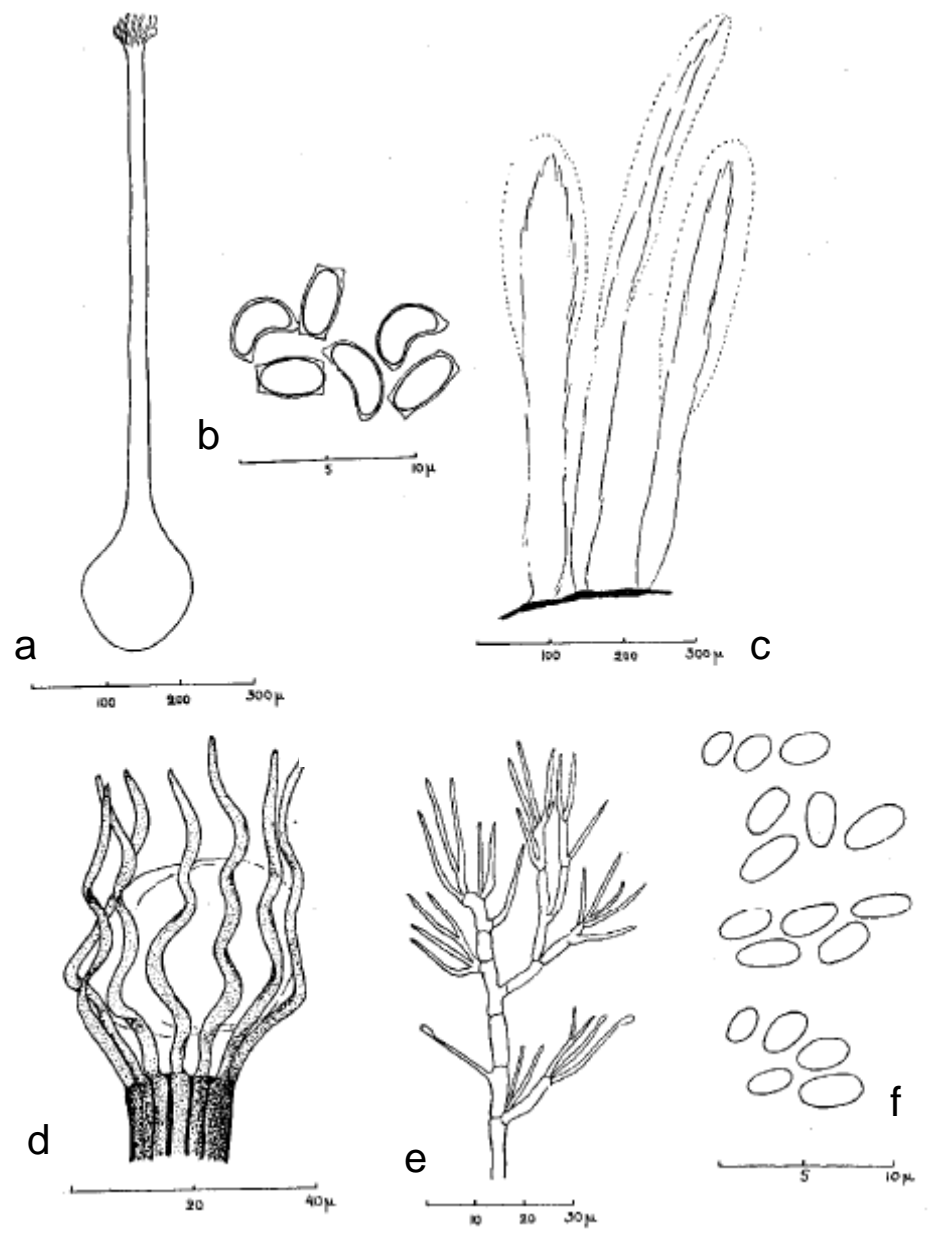



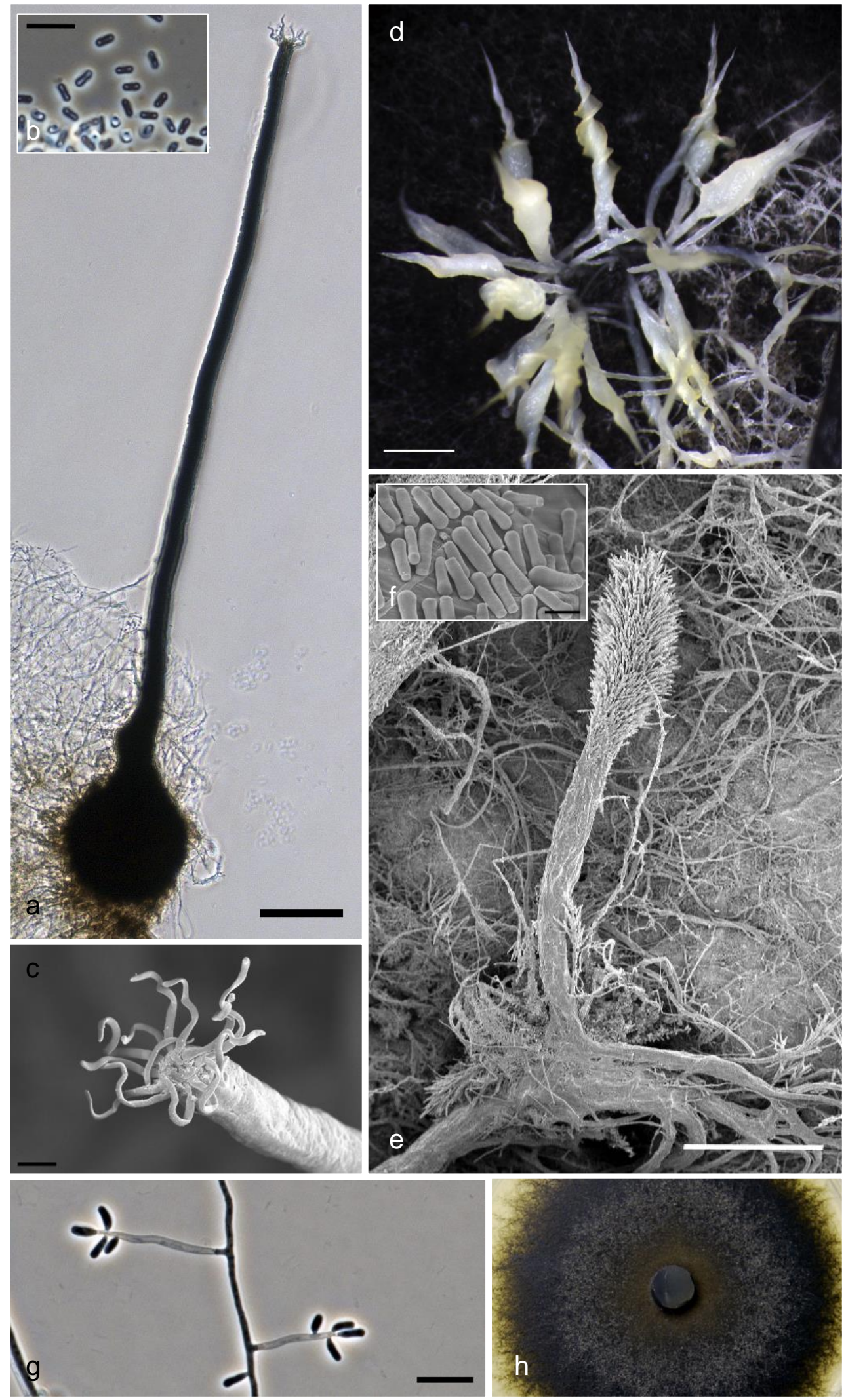


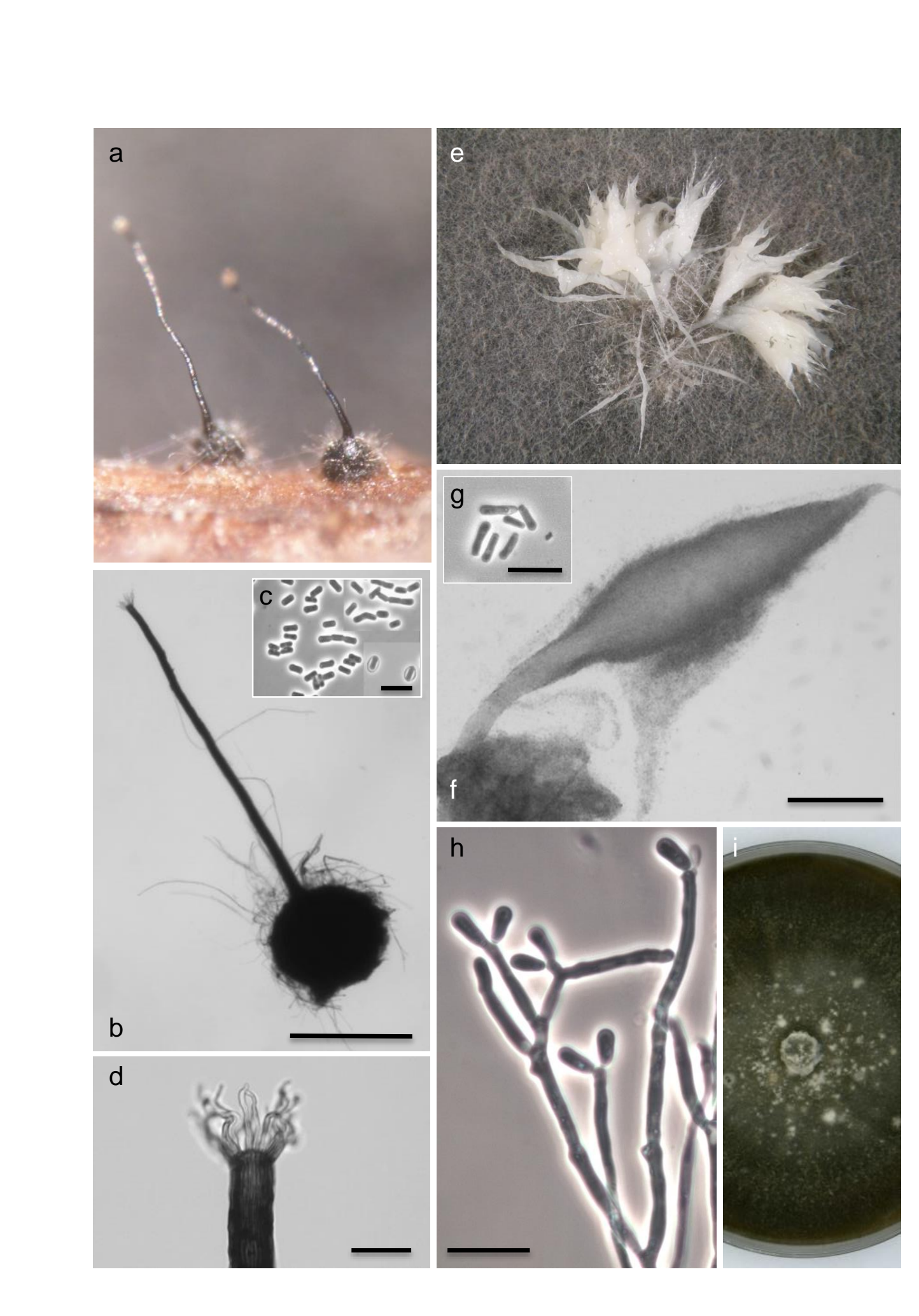

Figure 11

.
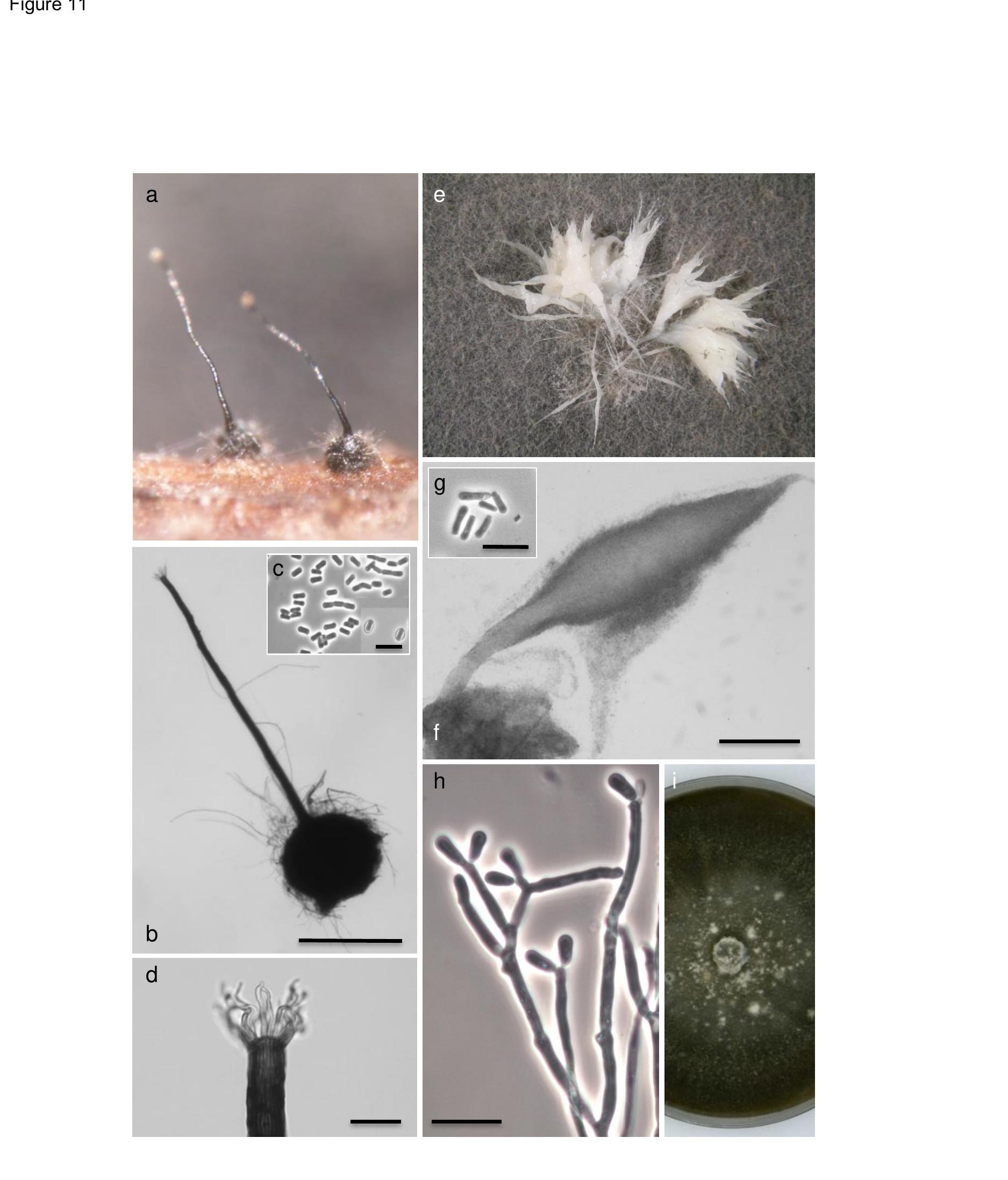
Table 1. Ophiostoma clavatum complex isolates and herbarium specimens examined in this study.

\begin{tabular}{|c|c|c|c|c|c|c|c|c|c|c|c|}
\hline \multirow[t]{2}{*}{ Species } & \multicolumn{2}{|c|}{ Isolate numbers $^{1}$} & \multirow[t]{2}{*}{ Herbarium } & \multirow[t]{2}{*}{ Origin } & \multirow[t]{2}{*}{ Host } & \multirow[t]{2}{*}{ Insect vector } & \multirow[t]{2}{*}{ Collector } & \multicolumn{4}{|c|}{ GenBank accession no. } \\
\hline & CMW & CBS & & & & & & ITS & $\beta$-tubulin & TEF $1-\alpha$ & CAL \\
\hline \multirow[t]{3}{*}{ O. ainoae } & $1037^{\top}$ & $205.83^{\top}$ & CBS H-3559 ${ }^{H}$ & Norway & Picea abies & Ips typographus & H. Solheim & KU094682 & HM031552 & KU094745 & KU094779 \\
\hline & 1903 & 118672 & & Norway & P. abies & I. typographus & H. Solheim & HM031495 & HM031553 & KU094746 & KU094780 \\
\hline & 23123 & 128299 & & Ohtama, Russia & P. abies & I. typographus & J. Ahtiainen & HM031496 & HM031550 & KU094747 & KU094781 \\
\hline \multirow[t]{16}{*}{ O. brunneo-ciliatum } & 39826 & 141265 & & Wierzchosławice, & Larix decidua & Ips cembrae & R. Jankowiak & & KU094687 & KU094748 & KU094782 \\
\hline & & & & Poland & & & & & & & \\
\hline & $39827^{a, b}$ & 141266 & TUR 205571 & Pateraki, Poland & & I. sexdentatus & R. Jankowiak & KU094683 & KU094688 & KU094749 & KU094783 \\
\hline & & & & & sylvestris & & & & & & \\
\hline & $39828^{\mathrm{a}}$ & 141267 & & Wierzchosławice, & L. decidua & Ips cembrae & R. Jankowiak & & KU094689 & KU094750 & KU094784 \\
\hline & & & & Poland & & & & & & & \\
\hline & 39829 & & & Wierzchosławice, & L. decidua & I. cembrae & R. Jankowiak & & KU094690 & KU094751 & KU094785 \\
\hline & & & & Poland & & & & & & & \\
\hline & $39842^{\mathrm{a}}$ & 141268 & & Babimost, Poland & P. sylvestris & I. sexdentatus & R. Jankowiak & & KU094691 & KU094752 & KU094786 \\
\hline & & & UPS:BOT:F- & Jokkmokk, Sweden & P. sylvestris & I. sexdentatus & E. Rennerfelt & & & & \\
\hline & & & $130962^{\mathrm{L}}$ & & & & & & & & \\
\hline & & & BPI 595721 & Jokkmokk, Sweden & P. sylvestris & I. sexdentatus & A. Mathiesen-Käärik & & & & \\
\hline & & & UPS:BOT:F- & Jokkmokk, Sweden & P. sylvestris & I. sexdentatus & E. Rennerfelt & & & & \\
\hline & & & 130963 & & & & & & & & \\
\hline & & & UPS:BOT:F- & Jokkmokk, Sweden & P. sylvestris & I. sexdentatus & E. Rennerfelt & & & & \\
\hline & & & 130964 & & & & & & & & \\
\hline
\end{tabular}




$\begin{array}{lllll}\text { UPS:BOT:F- } & \text { Jokkmokk, Sweden } & \text { P. sylvestris } & \text { I. sexdentatus } & \text { E. Rennerfelt } \\ 130965 & & & \\ \text { UPS:BOT:F- } & \text { Jokkmokk, Sweden } & \text { P. sylvestris } & \text { I. sexdentatus } & \text { E. Rennerfelt }\end{array}$

130967

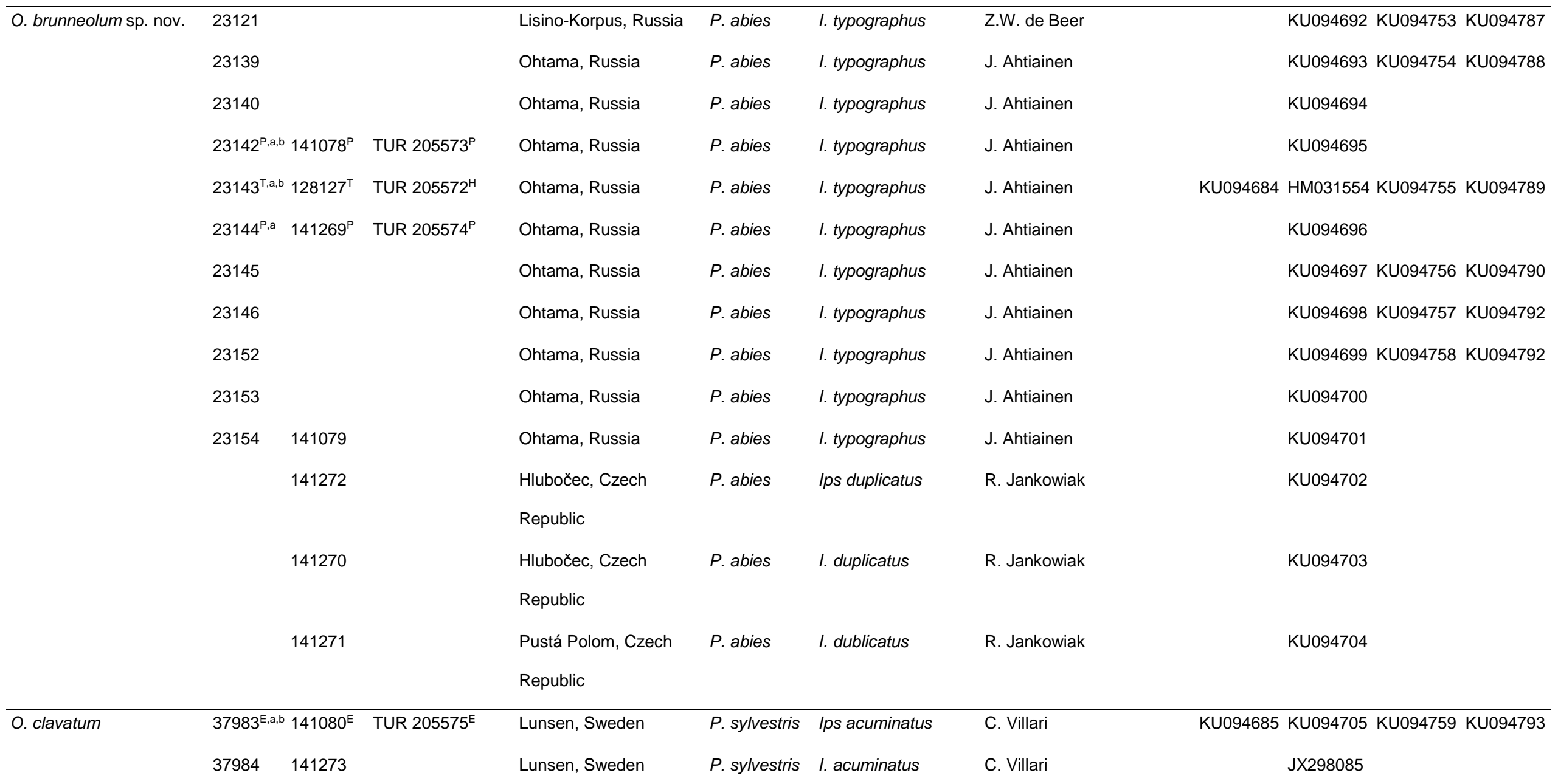




\begin{tabular}{|c|c|c|c|c|c|c|c|}
\hline 37985 & & & Val Dogna, Italy & P. sylvestris & I. acuminatus & C. Villari & KU094706 \\
\hline $37986^{\mathrm{a}}$ & & & Val Venosta, Italy & P. sylvestris & I. acuminatus & C. Villari & KU094707 KU094760 KU094794 \\
\hline 37987 & & & Val Camonica, Italy & P. sylvestris & I. acuminatus & C. Villari & KU094708 \\
\hline $37988^{\mathrm{a}}$ & 141274 & TUR 205576 & Var, France & P. sylvestris & I. acuminatus & A. Yart & KU094709 KU094761 KU094795 \\
\hline $41041^{*}$ & & & Sweden (?) & - & - & - & KU094710 KU094762 KU094796 \\
\hline $41042^{*}$ & & & Sweden (?) & - & - & - & KU094711 \\
\hline 41043 & & & Buskerud, Norway & P. sylvestris & I. acuminatus & H. Solheim & KU094712 KU094763 KU094797 \\
\hline 41045 & & & Buskerud, Norway & P. sylvestris & I. acuminatus & H. Solheim & KU094713 \\
\hline 41051 & & & Sweden & - & - & & KU094714 \\
\hline 41052 & & & San Vito, Italy & Pinus sp. & - & B. Långström & KU094715 \\
\hline 41122 & 141182 & & Bleiberg, Austria & P. sylvestris & I. acuminatus & T. Kirisits, G. Hoch & KU094716 \\
\hline $41123^{a, b}$ & 141183 & TUR 205577 & Bleiberg, Austria & P. sylvestris & I. acuminatus & T. Kirisits, G. Hoch & KU094717 KU094764 KU094798 \\
\hline 41124 & 141184 & & Bleiberg, Austria & P. sylvestris & I. acuminatus & T. Kirisits, G. Hoch & KU094718 \\
\hline 41125 & 141185 & & Bleiberg, Austria & P. sylvestris & I. acuminatus & T. Kirisits, G. Hoch & KU094719 \\
\hline 41126 & 141186 & & Bleiberg, Austria & P. sylvestris & I. acuminatus & T. Kirisits, G. Hoch & KU094720 \\
\hline 41127 & 141187 & & Bleiberg, Austria & P. sylvestris & I. acuminatus & T. Kirisits, G. Hoch & KU094721 \\
\hline \multirow[t]{3}{*}{41128} & 141188 & & Bleiberg, Austria & P. sylvestris & I. acuminatus & T. Kirisits, G. Hoch & KU094722 \\
\hline & & UPS:BOT:F- & Dalarna, Sweden & P. sylvestris & I. acuminatus & E. Rennerfelt & \\
\hline & & $\mathrm{F} 130972^{\mathrm{L}}$ & & & & & \\
\hline $23115^{T, a, b}$ & ${ }^{b} 141081^{\top}$ & TUR $205578^{\mathrm{H}}$ & Lisino-Korpus, Russia & P. sylvestris & $\begin{array}{l}\text { Pityogenes } \\
\text { chalcographus }\end{array}$ & Z.W. de Beer & HM031499 KU094723 KU094765 KU094799 \\
\hline $23116^{\mathrm{PT}, \mathrm{b}}$ & $141082^{P}$ & TUR $205579^{P}$ & Lisino-Korpus, Russia & P. abies & P. chalcographus & Z.W. de Beer & KU094724 KU094766 KU094800 \\
\hline 23117 & 141083 & & Lisino-Korpus, Russia & P. abies & I. typographus & Z.W. de Beer & KU094725 KU094767 KU094801 \\
\hline
\end{tabular}




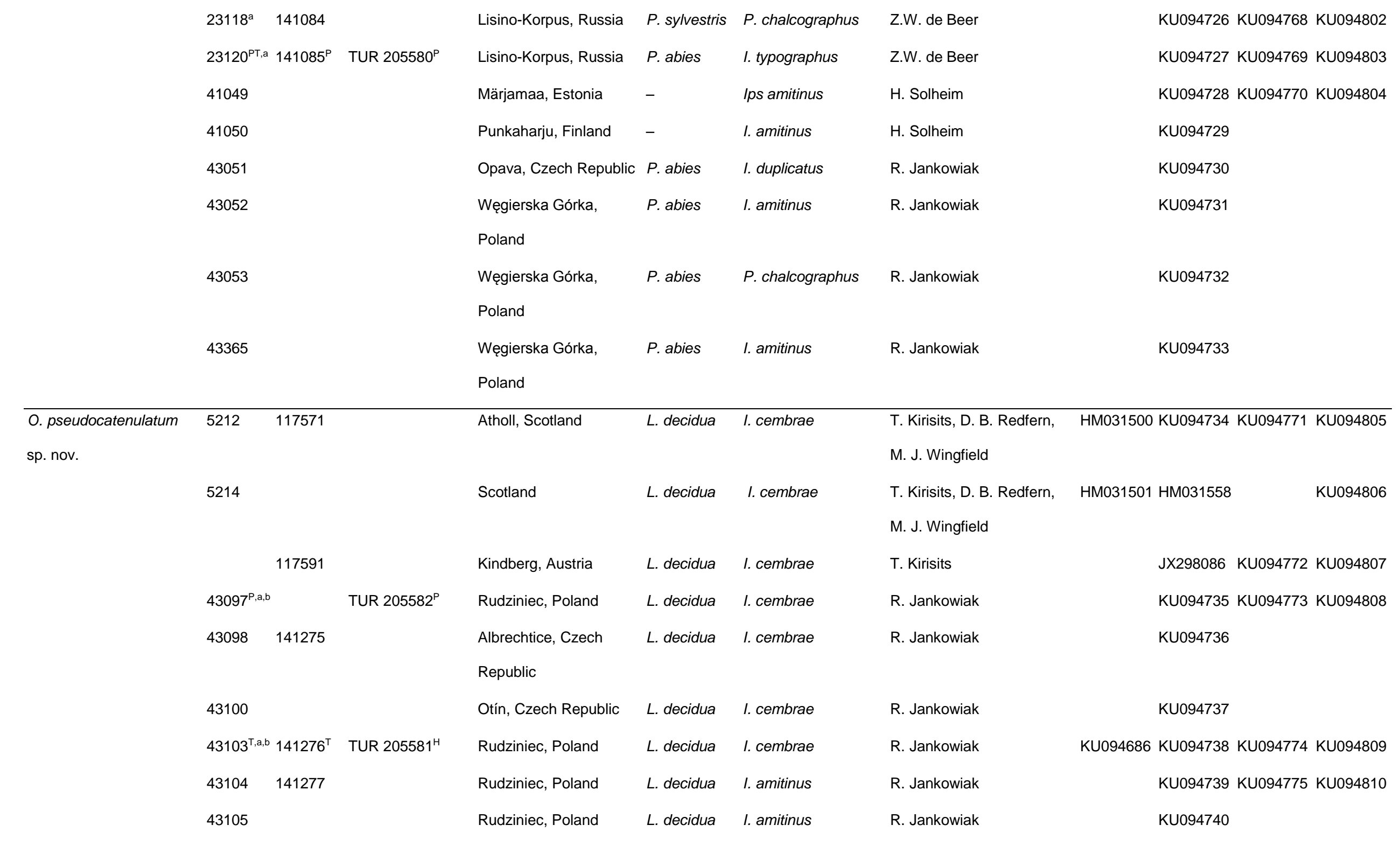




\begin{tabular}{|c|c|c|c|c|c|c|c|}
\hline $43106^{P, a, b}$ & $141278^{P T}$ & TUR $205583^{P}$ & Rudziniec, Poland & L. decidua & I. amitinus & R. Jankowiak & KU094741 \\
\hline \multirow[t]{2}{*}{43107} & & & Albrechtice, Czech & L. decidua & I. cembrae & R. Jankowiak & KU094742 KU094776 KU094811 \\
\hline & & & Republic & & & & \\
\hline 43108 & & & Rudziniec, Poland & L. decidua & 1. cembrae & R. Jankowiak & KU094743 \\
\hline \multirow[t]{2}{*}{43598} & 141279 & & Albrechtice, Czech & L. decidua & I. cembrae & R. Jankowiak & KU094744 \\
\hline & & & Republic & & & & \\
\hline $23265^{\top}$ & $128120^{\top}$ & KUO $021872^{\mathrm{H}}$ & Lisino-Korpus, Russia & P.sylvestris & Hylurgops palliatus & Z.W. de Beer & HM031494 HM031545 KU094777 KU094812 \\
\hline $23266^{P}$ & $128122^{P}$ & KUO $021873^{P}$ & Punkaharju, Finland & P. sylvestris & Hylastes brunneus & Z.W. de Beer & HM031493 HM031544 KU094778 KU094813 \\
\hline
\end{tabular}

${ }^{1}$ CBS: Centraalbureau voor Schimmelcultures, Utrecht, The Netherlands; CMW: Culture Collection of the Forestry and Agricultural Biotechnology Institute (FABI), University of Pretoria, Pretoria, South

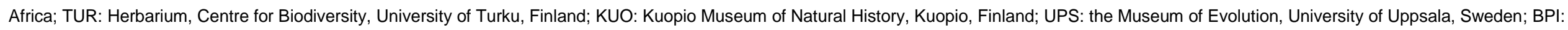
U.S. National Fungus Collections, USDA, Beltsville, USA

${ }^{a}$ Isolates used in growth studies; ${ }^{\mathrm{b}}$ Isolates used in morphological descriptions; ${ }^{\top}$ Type/Ex-type; ${ }^{\mathrm{E}}$ Epitype/Ex-epitype; ${ }^{\mathrm{P}}$ Paratype/Ex-paratype; ${ }^{\mathrm{H}}$ Holotype; ${ }^{\mathrm{L}}$ Lectotype

* Isolates might represent original material from Mathiesen (1951) 
Table 2. Morphological comparisons of the lectotype specimen, the reference culture, and the previous descriptions of Ophiostoma brunneo-ciliatum*

\begin{tabular}{|c|c|c|c|c|c|}
\hline Character & $\begin{array}{l}\text { Lectotype } \\
\text { UPS F-130962 }\end{array}$ & $\begin{array}{l}\text { Reference culture } \\
\text { CMW } 39827\end{array}$ & Mathiesen-Käärik 1953 & Hunt 1956 & Upadhyay 1981 \\
\hline Perithecia & & Not observed & & & \\
\hline Color & Black & & Black & Black & Dark brown to black \\
\hline Base diameter & $176-(198-271(-290) \mu \mathrm{m}$ & & $(192-) 246(-283) \mu m$ & $160-220 \mu \mathrm{m}$ & $(150-) 200-350(-380) \mu \mathrm{m}$ \\
\hline Ornamentation & $\begin{array}{l}\text { Sparsely ornamented with (24- } \\
) 57-125(140) \times 1.5-2(-2.5) \mu \mathrm{m} \\
\text { long brown hyphae }\end{array}$ & & $\begin{array}{l}\text { Up to } 200 \mu \mathrm{m} \text { long, greyish } \\
\text { hyphae }\end{array}$ & $\begin{array}{l}\text { Sparsely ornamented with } \\
\text { brown, branched hyphae }\end{array}$ & $\begin{array}{l}\text { Mid brown to brown } \\
\text { unbranched or branched } \\
\text { hyphae present }\end{array}$ \\
\hline Neck length & $(608-) 794-1129(-1136) \mu \mathrm{m}$ & & $\begin{array}{l}(850-) 1330(-1760) \mu \mathrm{m}, \text { neck } \\
\text { has often pointed, knob-like } \\
\text { protrusions }\end{array}$ & Up to $1400 \mu \mathrm{m}$ & $(550-) 590-1250(-1700) \mu \mathrm{m}$ \\
\hline Neck base width & $(32-) 36-48(-55) \mu \mathrm{m}$ & & $(34-) 45(-47) \mu \mathrm{m}$ & $30-40 \mu \mathrm{m}$ & $30-45(-57.5) \mu \mathrm{m}$ \\
\hline Neck apex width & $(15-) 16-20 \mu \mathrm{m}$ & & $(17-) 20(-23) \mu \mathrm{m}$ & $19-24 \mu \mathrm{m}$ & $15-25(-30) \mu \mathrm{m}$ \\
\hline Ostiolar hyphae & $\begin{array}{l}(37-) 38-52(-63) \mu \mathrm{m} \text { long, } \\
\text { brown, spirally curved }\end{array}$ & & $\begin{array}{l}(12-) 18(-20) \text { in number, } 28-43 \\
\mu m \text { long, brown, spirally curved }\end{array}$ & $\begin{array}{l}\text { Numerous, up to } 70 \mu \mathrm{m} \text { long, } \\
\text { pale brown, shaped like a } \\
\text { corkscrew }\end{array}$ & $\begin{array}{l}\text { Absent or } 22-57,5(-80) \mu \mathrm{m} \\
\text { when present, brown to pale } \\
\text { brown, spirally curved }\end{array}$ \\
\hline Ascospores & $\begin{array}{l}\text { Rectangular, (2-)3.5-4.5(-5.5) } \\
\times 1.5-2(-2.5) \mu \mathrm{m}\end{array}$ & & Rectangular, $4 \times 1.8 \mu \mathrm{m}$ & Rectangular, $4-5 \times 2 \mu \mathrm{m}$ & $\begin{array}{l}\text { Rectangular, } 3.5-5 \times 1.5-2.5(- \\
\text { 3) } \mu \mathrm{m}\end{array}$ \\
\hline Asexual state & & & & & \\
\hline Synnematal & Not observed & Not observed & $\begin{array}{l}\text { Graphium (brush-like); } \\
\text { synnemata } 800-1500(-2500) \\
\mu m \text { long, } 16-60 \mu \mathrm{m} \text { wide, } \\
\text { black; conidia }(4-) 5.7(-6.8) \times\end{array}$ & $\begin{array}{l}\text { Graphium (brush-like); } \\
\text { synnematal stipes } 1500 \times 80 \\
\mu \mathrm{m} \text {, brown, heads up to } 100 \\
\mu \mathrm{m} \text { in diameter; conidia } 4.5-6 \times\end{array}$ & $\begin{array}{l}\text { Pesotum (brush-like); } \\
\text { synnemata 100-3600(-4000) } \\
\mu \mathrm{m} \text { including conidiogenous } \\
\text { apparatus, } 15-70 \text { wide, brown }\end{array}$ \\
\hline
\end{tabular}


$\times 1-2(-2.5) \mu \mathrm{m}$

Hyalorhinocladiella-like; conidiogenous cells (6-)11-

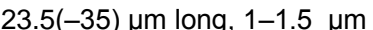

wide; conidia (3-)3.5-4.5(-5)

$\mu \mathrm{m} \times 1-1.5(-2) \mu \mathrm{m}$

\section{Cultures}

Growth rate

Color

Origin

Sweden

Insect vector and host
$6.15( \pm 0.3) \mathrm{mm} /$ day $\left(20^{\circ} \mathrm{C}\right), 8.9$

$( \pm 0.2) \mathrm{mm} /$ day $\left(25^{\circ} \mathrm{C}\right)$

Hyaline at first, becoming dark

brown to black

Poland

I. sexdentatus on $P$. sylvestris
Cephalosporium-like; conidia

Cephalosporium-like;

conidiophores $10-30 \mu \mathrm{m}$ long

$(4.2-) 6.8(-8.9) \times(2.5-) 3.1(-$

Not reported

4.3) $\mu \mathrm{m}$ 
Table 3. Morphological comparisons of the lectotype specimen, ex-epitype culture, and the previous descriptions of Ophiostoma clavatum.

\begin{tabular}{|c|c|c|c|c|}
\hline Character & $\begin{array}{l}\text { Lectotype } \\
\text { UPS F-130972 }\end{array}$ & $\begin{array}{l}\text { Ex-epitype } \\
\text { CMW } 37983\end{array}$ & Mathiesen 1951 & Hunt 1956 \\
\hline Perithecia & & Not observed & & Not observed* \\
\hline Color & Black & & Brownish black & \\
\hline Base diameter & $121-148 \mu \mathrm{m}$ & & $(127-) 177-238 \mu \mathrm{m}$ & \\
\hline Ornamentation & Absent & & Absent & \\
\hline Neck length & $559-591 \mu \mathrm{m}$ & & (453-)566-(830) $\mu \mathrm{m}$ & \\
\hline Neck base width & $34-43 \mu \mathrm{m}$ & & $(28.3-) 35.9(-45.3) \mu \mathrm{m}$ & \\
\hline Neck apex width & $15-19 \mu \mathrm{m}$ & & $(11.3-) 15.8(-19.8) \mu \mathrm{m}$ & \\
\hline Ostiolar hyphae & $\begin{array}{l}12-13 \text { in number, (16-)24-40(-44) } \\
\mu m \text { long, spirally curved }\end{array}$ & & $\begin{array}{l}\text { 9-12 in number, (14-)52.2(-81.2) } \mu \mathrm{m} \\
\text { long, spirally curved }\end{array}$ & \\
\hline Ascospores & $\begin{array}{l}\text { Cylindrical to rectangular, (3-)3.5-4(- } \\
6.5) \times(1-) 1.5(-2) \mu \mathrm{m}\end{array}$ & & $\begin{array}{l}\text { Long-elliptic or orange section } \\
\text { shaped, } 3.3 \times 1.4 \mu \mathrm{m}\end{array}$ & \\
\hline Asexual state & & & & \\
\hline Synnematal & Not observed & $\begin{array}{l}\text { Pesotum (brush-like); synnemata } \\
\text { rarely produced in culture, (959- } \\
\text { 1123-1515(-1636) } \mu \mathrm{m} \text { long, (32- } \\
\text { )41-64(-78) } \mu \mathrm{m} \text { wide at base, hyaline } \\
\text { to brown; conidia cylindrical to } \\
\text { ellipsoid, }(3.5-) 4-5(-5.5) \times 1.5-2 \mu \mathrm{m}\end{array}$ & $\begin{array}{l}\text { Pesotum (brush-like); synnemata } \\
\text { 150-500 } \mu \mathrm{m} \text { long, } 40-200 \mu \mathrm{m} \text { wide, } \\
\text { brown; conidia ellipsoid, }(2.7-) 3.2(- \\
3.5) \times(1.7-) 1.9(-2.1) \mu \mathrm{m}\end{array}$ & $\begin{array}{l}\text { Pesotum (brush-like); synnemata } \\
\text { rarely produced in culture, } 500 \mu \mathrm{m} \\
\text { long, } 50 \mu \mathrm{m} \text { wide, brown; conidia } \\
\text { cylindrical to ellipsoid, } 4-6 \times 2-2.5 \mu \mathrm{m}\end{array}$ \\
\hline Mononematal & Not observed & $\begin{array}{l}\text { Hyalorhinocladiella-like; } \\
\text { conidiogenous cells }(2-) 7.5-21(-35) \\
\text { long, (1-)1.5-2(-3.5) } \mu \mathrm{m} \text { wide; conidia }\end{array}$ & $\begin{array}{l}\text { Cephalosporium-like; conidia (5.1- } \\
\text { 6.3. }(-7.4) \times(2.2-) 2.9(-4.2) \mu \mathrm{m}\end{array}$ & $\begin{array}{l}\text { Conidiophores up to } 35 \mu \mathrm{m} \text { long and } 2 \\
\mu \mathrm{m} \text { wide; conidia as in synnematal } \\
\text { anamorph }\end{array}$ \\
\hline
\end{tabular}




\section{Cultures}

Growth rate

Color

Origin

Insect vector and host
Sweden

I. acuminatus on $P$. sylvestris
$4( \pm 0.8) \mathrm{mm} /$ day $\left(20^{\circ} \mathrm{C}\right), 6( \pm 0.3)$

$\mathrm{mm} /$ day $\left(25^{\circ} \mathrm{C}\right)$

Hyaline at first, becoming dark brown

to black

Sweden

I. acuminatus on $P$. sylvestris
Hyaline at first, becoming dark green to dark brown

Sweden

I. acuminatus on $P$. sylvestris
Hyaline at first, becoming dark olive green to black

Sweden

I. acuminatus on $P$. sylvestris

* Hunt (1956) used Mathiesen's (1951) measurements for the description of the ascomatal characteristics. 